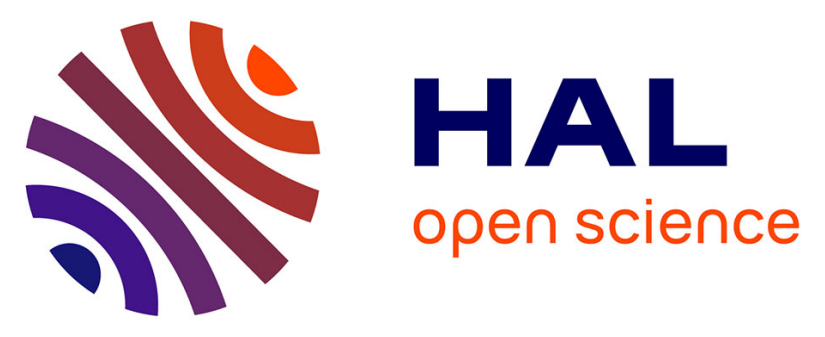

\title{
A new ternary ruthenium(III) complex with 1,3-bis(salicylideneamino) propan-2-ol and 3-picolylamine: Synthesis, characterization, density functional theory and preparation of electrochemical sensor for nitrite analysis.
}

Achour Terbouche, Chafia Ait-Ramdane-Terbouche, Safia Djebbar, Djamila Guerniche, Radia Bagtache, Nour El Houda Bensiradj, Amar Saal, Didier Hauchard

\section{To cite this version:}

Achour Terbouche, Chafia Ait-Ramdane-Terbouche, Safia Djebbar, Djamila Guerniche, Radia Bagtache, et al.. A new ternary ruthenium(III) complex with 1,3-bis(salicylideneamino) propan-2-ol and 3-picolylamine: Synthesis, characterization, density functional theory and preparation of electrochemical sensor for nitrite analysis.. Journal of Molecular Structure, 2014, 1076, pp.501-511. 10.1016/j.molstruc.2014.08.013 . hal-01069488

\section{HAL Id: hal-01069488 https://hal.science/hal-01069488}

Submitted on 8 Oct 2014

HAL is a multi-disciplinary open access archive for the deposit and dissemination of scientific research documents, whether they are published or not. The documents may come from teaching and research institutions in France or abroad, or from public or private research centers.
L'archive ouverte pluridisciplinaire HAL, est destinée au dépôt et à la diffusion de documents scientifiques de niveau recherche, publiés ou non, émanant des établissements d'enseignement et de recherche français ou étrangers, des laboratoires publics ou privés. 


\title{
A new ternary ruthenium (III) complex with 1,3-bis (salicylideneamino) propan-2-ol and 3-
} picolylamine: Synthesis, characterization, density functional theory and preparation of electrochemical sensor for nitrite analysis.

Achour Terbouche ${ }^{\mathrm{a}, \mathrm{b},{ }^{*}}$, Chafia Ait-Ramdane-Terbouche ${ }^{\mathrm{a}, \mathrm{b}}$, Safia Djebbar ${ }^{\mathrm{b}}$, Djamila Guerniche, ${ }^{\mathrm{a}, \mathrm{c}}$, Radia Bagtache $^{c}$, Nour El Houda Bensiradj ${ }^{\mathrm{d}}$, Amar Saal $^{\mathrm{d}}$, Didier Hauchard ${ }^{\mathrm{e}}$,

${ }^{a}$ Centre de Recherche Scientifique et Technique en Analyses Physico-chimiques (CRAPC), Algiers, 16004, Algeria

baboratoire d'Hydrométallurgie et Chimie Inorganique Moléculaire, Faculté de Chimie, USTHB University, 16111, Algiers, Algeria

'Laboratoire d'Electrochimie-Corrosion, Métallurgie et Chimie Minérale, Faculté de Chimie, USTHB University, 16111, Algiers, Algeria

${ }^{\mathrm{d}}$ Laboratoire de Physico-Chimie Théorique et Chimie Informatique, Faculté de chimie, USTHB University, 16111, Algiers, Algeria

eSciences Chimiques de Rennes, UMR CNRS 6226, Ecole Nationale Supérieure de Chimie de Rennes, avenue du général Leclerc, CS 50837, 35708 Rennes Cedex 7, France

${ }^{\mathrm{f}}$ Université Européenne de Bretagne, 12 avenue Janvier, 35000 Rennes, France

\begin{abstract}
A novel electrochemical sensor based on graphite $(\mathrm{G})$ functionalised with a new ternary ruthenium (III) complex was developed and applied to detect nitrite in aqueous solution. The Ru (III) complex was synthesized using 1,3-bis(salicylideneamino) propan-2-ol polydentate Schiff base (BSAP) and 3Picolylamine (PLA), and was characterized by elemental analysis, Fourier transform infrared spectroscopy (FT-IR), Ultraviolet-visible spectrophotometry (UV-Visible), gradient-assisted hetero nuclear single quantum coherence spectroscopy (gHSQC) and cyclic voltammetry technique. In addition, the structure of the synthesized complex was optimized using density functional theory (DFT). The results showed that the ternary Ru(III)-BSAP-PLA complex was formed and the adapted structure was an tetrahedral geometry.
\end{abstract}


The electrochemical behavior of nitrite at the sensor prepared using G/Ru(III)-BSAP-PLA composite shows that the evaluated electron transfer coefficient $(a=0.83)$ indicates a very significant electrocatalytic mechanism for oxidation of nitrite in the presence of the Ru(III)-BSAP-PLA complex. Comparing to other published works, the sensor developed using G/Ru(III)-BSAP-PLA exhibited low limit of detection $(L O D=1.81 \mu \mathrm{M})$ around $\mathrm{pH}=7$.

Keywords: Ruthenium (III) complex; Characterization; DFT calculation; Electrochemical sensor.

\section{Introduction}

Schiff bases are the organic molecules containing a carbon-nitrogen double bond with the nitrogen atom bonded to an aryl or alkyl group. Generally, they have a second functional group such as hydroxyl near the imine function. These polydentate ligands lead to the formation of more stable chelates with transition metals, which are often insoluble in water. The use of these solid complexes to modify electrodes is very important for application in electroanalysis field. Previously, the carbon electrodes modified by insoluble electro active compounds have been used in electroanalytical chemistry [1-13].

Rrecently, numerous studies have been conducted on the impact of inorganic pollutants such as heavy metals and nitrite ions on water quality [14-20]. Indeed, to detect these ions, different electrochemical sensors based on modified electrodes were developed [21-30].

*Corresponding authors:

Tel.: 00213.778.815.933,fax: 00213.21.24.74.06. E-mail address: achour_t@yahoo.fr (Achour TERBOUCHE) 
To our knowledge, to determine nitrite ions, there have been no previous published works citing the use of cavity microelectrode modified with ternary complexes. In this paper, after characterization of the ternary complex formed with 1,3-bis(salicylideneamino)propan-2-ol (BSAP) and 3-Picolylamine (PLA) (Scheme 1) and G/Ru(III)-BSAP-TLA composite material using different techniques such as elemental analysis, FT-IR, UV-Vis, gHSQC, molecular modeling and SEM-EDS, a new sensor based on cavity microelectrode modified with graphite-ruthenium (III) complex composite (CME/G/Ru(III)BSAP-TLA) was developed to detect and nitrite ions by using electrocatalytic oxidation process. The electrochemical study showed that the CME/G/Ru(III)-BSAP-TLA sensor exhibited a sensitive electrochemical response for the oxidation of $\mathrm{NO}_{2}{ }^{-}$, and the ternary $\mathrm{Ru}$ (III)-BSAP-TLA complex plays an important role in increasing the effectiveness of the sensor.

\section{Materials and methods}

\subsection{Apparatus, reagents and materials}

Fourier transform infrared spectra were recorded on a FT-IR Perkin-Elmer Spectrum One spectrometer using $\mathrm{KBr}$ pellets over the 4000 to $400 \mathrm{~cm}^{-1}$ range. For each measurement 32 scans were collected at a resolution of $4 \mathrm{~cm}^{-1}$. The electronic absorption measurements were performed on a Varian Cary 50 Conc UV-Vis Spectrophotometer using quartz cuvette with $1 \mathrm{~cm}$ path length. Nuclear magnetic resonance spectra and scanning electron microscopy analysis coupled with energy dispersive spectroscopy (SEM-EDS) were carried out using a DPX 200 NMR spectrometer and scanning electronic microscope Hitachi TM-1000, respectively.

The characterization of Ru(III)-BSAP-PLA complex by cyclic voltammetry method was investigated using a potentiostat/galvanostat Autolab® PGStat 30 equipped with glassy carbon (GC), $\mathrm{Ag} / \mathrm{AgCl}$ and Pt wire as working, reference and auxiliary electrode, respectively. 
In the study of electrochemical behavior of nitrite ions, the modified cavity microelectrode $(\mathrm{CME} / \mathrm{G} / \mathrm{Ru}(\mathrm{III})-\mathrm{BSAP}-\mathrm{PLA})$ was used as working electrode (diameter $\phi_{\mathrm{c}}=50 \mu \mathrm{m}$ and a depth $\mathrm{h}_{\mathrm{c}}=17$ $\mu \mathrm{m})$.

All chemicals used in this work were of the highest purity and analytical grade and the different solutions were prepared in free $\mathrm{CO}_{2}$ deionised water (resistivity $\geq 14 \mathrm{M} \Omega \mathrm{cm}$ ). The buffer $\mathrm{NaH}_{2} \mathrm{PO}_{4} / \mathrm{Na}_{2} \mathrm{HPO}_{4}(0.1 \mathrm{M})$ was used to keep the $\mathrm{pH}$ of the solutions constant $(\mathrm{pH}=7)$.

All experiments were carried out at room temperature under a nitrogen atmosphere.

\subsection{Synthesis of the ternary complex (Ru(III)-BSAP-PLA)}

The ligand 1,3-bis(salicylideneamino)propan-2-ol (Scheme 1a) was synthesized following the procedure reported by Kruger et al. [31]. The 3-picolylamine ligand (Scheme 1b) was pure Fluka product (Ref. No. 2230910, pure 99\%).

The $\mathrm{Ru}(\mathrm{III})$-BSAP-PLA complex was prepared by the addition of $\mathrm{Ru}(\mathrm{III})$ chloride hydrate (1 mmol) to a mixture acetone solution of 1,3-bis(2-hydroxysalicylideamino)propan-2-ol (2 mmol) and 3picolylamine (4 mmol) (Scheme 1). The resulting mixture was stirred, slightly heated and then some drops of sodium hydroxide $(0.1 \mathrm{M})$ were added slowly. The resulting green solution was stirred and heated over a 48 hours period. The formed dark precipitate was then collected and watched with deionized water. (Yield 70\%, $0.652 \mathrm{~g}$ ). Analytical calculation for Ru(III) complex: C(54.54\%); $\mathrm{H}(4.97 \%) ; \mathrm{N}(11.06 \%) ; \quad \mathrm{O}(9.48 \%) ; \mathrm{Ru}(19.95 \%)$. Found: $\mathrm{C}(53.99 \%) ; \mathrm{H}(4.37 \%) ; \mathrm{N}(11.77 \%)$; $\mathrm{O}(10.32 \%) ; \mathrm{Ru}(19.55 \%)$

The synthesized complex is insoluble in water, soluble in dimethyl sulfoxide (DMSO) and acetonitryle and shows less solubility in other organic solvents such as dimethylformamide (DMF) and dichloromethane. The molar conductivity value of $\mathrm{Ru}(\mathrm{III})$-BSAP-PLA complex in DMSO (55.15 $\Omega^{-1}$ $\mathrm{cm}^{2} \mathrm{~mol}^{-1}$ ) indicating a non-electrolytic nature. 


\subsection{Theoretical study of the ruthenium complex}

Geometry optimization and vibrational frequency analysis were performed using DFT approach with the M06 level [32] and relativistic effective core potential basis set of double zeta quality, Lanl2dz [33], as implemented in Gaussian03 program package [34]. This technique is the best method to predict the geometry of the metal transition complexes.

In this part of the work, we optimized the geometry of the octahedral and tetrahedral forms of the ruthenium (III) complex. Each geometry optimization was completed by a calculation of harmonic vibrational frequencies to confirm the most stable geometry.

The studied forms of the $\mathrm{Ru}(\mathrm{III})$ complex were characterized as minima (no imaginary frequency) in their potential energy surface through harmonic frequency analysis.

\subsection{Preparation of G/Ru(III)-BSAP-PLA composite and the modified cavity microelectrode}

The $\mathrm{G} / \mathrm{Ru}(\mathrm{III})-\mathrm{BSAP}-\mathrm{PLA}$ composite material was prepared by adding $50 \mathrm{mg}$ of treated graphite powder to 0.1 M DMSO solution of Ru(III) complex. The mixture was slowly stirred for 48 hours, and was then centrifuged. The solid product was dried at room temperature, washed with distilled water, and finally dried under vacuum.

To prepare $\mathrm{CME} / \mathrm{G} / \mathrm{Ru}(\mathrm{III})-\mathrm{BSAP}-\mathrm{PLA}$ modified electrode, the CME was filled with active material by pressing the electrode tip into the $\mathrm{G} / \mathrm{Ru}(\mathrm{III})$-BSAP-PLA powder.

After each measurement, $\mathrm{CME}$ was washed with an ultrasonic cleaner using successively $\mathrm{HNO}_{3}$ solution (1 M), $\mathrm{H}_{2} \mathrm{O}_{2}(30 \%)$ and deionised water.

\section{Results and discussion}

\subsection{FT-IR spectrometry}


To determine the coordination mode between ruthenium (III) and the two ligands (BSAP and PLA), we compared the FT-IR spectrum of the complex with those of the uncomplexed ligands (Fig. 1). This comparison also allowed identifying the sites involved in the formation of bonds in the complex.

1,3-bis(2-hydroxysalicylideamino)propan-2-ol shows vibration peaks at 3399, 1634, 1276, 1207 and $1049 \mathrm{~cm}^{-1}$, attributed to the stretching vibration $(v)$ of $\mathrm{OH}$ (phenolic hydroxyl group), $\mathrm{C}=\mathrm{N}, \mathrm{C}-\mathrm{N}$ and $\mathrm{C}-\mathrm{O}(\mathrm{C}-\mathrm{OH}$ group) and to the deformation vibration $(\delta)$ of $\mathrm{OH}$ groups, respectively. While, 3picolylamine shows vibration bands at 3368,1583 and $1312 \mathrm{~cm}^{-1}$, assigned to $v_{\mathrm{N}-\mathrm{H}}, \delta_{\mathrm{N}-\mathrm{H}}$ and $v_{\mathrm{C}-\mathrm{N}}$ groups, respectively.

Compared to BSAP, the vibration bands of $\mathrm{C}=\mathrm{N}\left(1601 \mathrm{~cm}^{-1}\right)$ and $\mathrm{C}-\mathrm{O}\left(1231 \mathrm{~cm}^{-1}\right)$ in the complex underwent a shift to lower energies. The disappearance of the $\mathrm{OH}$ peak $\left(1207 \mathrm{~cm}^{-1}\right)$ of ligand and the shift of vibration bands of $\mathrm{C}=\mathrm{N}$ and $\mathrm{C}-\mathrm{O}$ in the spectrum of complex confirms that the ruthenium binds to the BSAP ligand by the lone pair of nitrogen and oxygen of the imines and C-O groups, respectively. The stretching vibration bands $v_{\mathrm{N}-\mathrm{H}}$ observed at $3399 \mathrm{~cm}^{-1}$ in the spectrum of 3-picolylamine was shifted to higher energies $\left(v_{\mathrm{N}-\mathrm{H}}: 3429 \mathrm{~cm}^{-1}\right)$ in the FT-IR spectrum of the complex, indicating that the metal is bonded with the nitrogen of the amine group.

The ruthenium-oxygen bonding is confirmed by the newly formed band that appear at $615 \mathrm{~cm}^{-1}$ which is assigned to the $\mathrm{Ru}-\mathrm{O}$ vibration. 


\subsection{UV-Visible spectrophotometry}

UV-Visible absorption spectrophotometry was used to determine the intra ligand, metal-ligand and d-d electronic transitions.

The electronic absorption of Ru(III)-BSAP-PLA, Ru(III) and BSAP-PLA compounds were recorded in DMSO at room temperature. The used analytical concentration in this study is the same in all solutions $\left(10^{-4} \mathrm{M}\right)$.

The shoulder UV-Visible absorption at $375 \mathrm{~nm}\left(\varepsilon=8.1 \times 10^{+3} \mathrm{M}^{-1} \mathrm{~cm}^{-1}\right)$ assigned to ligands (Fig. Sb), corresponding to intra ligand transition $\pi \rightarrow \pi^{*}$, is shifted to lower wavelengths $\left(\lambda=315 \mathrm{~nm}, \varepsilon=1.2 \times 10^{+3}\right.$ $\mathrm{M}^{-1} \mathrm{~cm}^{-1}$ ) in the spectrum of the complex (Fig. Sc), indicating the commitment of the ligands in the formation of $\mathrm{Ru}(\mathrm{III})$-BSAP-PLA complex.

The absorption band observed at $414 \mathrm{~nm}\left(\varepsilon=6.96 \times 10^{+3} \mathrm{M}^{-1} \mathrm{~cm}^{-1}\right)$ in the spectrum of the metal (Fig. Sa) remains virtually unchanged in the spectrum of the complex $(\lambda=410 \mathrm{~nm})$, indicating the presence of the metal in this compound. The electronic absorption band at $410 \mathrm{~nm}\left(\varepsilon=1.16 \times 10^{+3} \mathrm{M}^{-1} \mathrm{~cm}^{-1}\right)$ in the spectrum of $\mathrm{Ru}(\mathrm{III})$-BSAP-PLA complex corresponds to metal-to-ligand $\mathrm{d}_{\pi(\mathrm{Ru})} \rightarrow \pi^{*}$ transition.

The broad UV-Visible absorption observed around $520 \mathrm{~nm}\left(\varepsilon=0.880 \times 10^{+3} \mathrm{M}^{-1} \mathrm{~cm}^{-1}\right)$ in the spectrum of the complex may be assigned to the $\mathrm{d}-\mathrm{d}$ transition band.

\subsection{Two-dimensional NMR Spectrometry}

The resonance of directly bonded proton carbon pairs $(\mathrm{C}-\mathrm{H})$ was carried out using gradient assisted hetero nuclear single quantum coherence spectroscopy (gHSQC) (Fig. S2).

The cross peaks between the ${ }^{13} \mathrm{C}$ resonance at $24 \mathrm{ppm}$ and $1 \mathrm{H}$ signals in the range of 1.2 to $1.4 \mathrm{ppm}$ were assigned to $\mathrm{CH}_{2}$ of $\underline{\mathrm{CH}_{2}}-\mathrm{NH}_{2}$ group of 3-picolylamine. The $\mathrm{C}-\mathrm{O}$ bond at $28 \mathrm{ppm}$ was also correlated with protons in the range of 1.4-1.7 ppm from the $\mathrm{CH}_{2}-\underline{\mathrm{CHO}}-\mathrm{CH}_{2}$ group. Additionally, the 
gHSQC cross peaks between the $1 \mathrm{H}$ signal at $1.2 \mathrm{ppm}$ and ${ }^{13} \mathrm{C}$ resonance at $30 \mathrm{ppm}$ correspond to the C-H bond in the $\mathrm{N}-\underline{\mathrm{CH}}_{2}$ groups. Whereas, the proton signals between 2 and 3 ppm showed the gHSQC correlations to the $\mathrm{Ar}-\underline{\mathrm{CH}}=\mathrm{N}$ carbon resonating between 30 and $40 \mathrm{ppm}$.

Finally, the gHSQC cross peak at 6.9, $125 \mathrm{ppm}$ and 7.3, $125 \mathrm{ppm}$ were assigned to the $\mathrm{C}-\mathrm{H}$ bonds in the aromatic and pyridine rings, respectively.

Moreover, the absence of the gHSQC cross peak at $7.2 \mathrm{ppm}$ corresponding to the $1 \mathrm{H}$ signal of $\mathrm{OH}$ group revealed that at least one $\mathrm{OH}$ function does not bind to the central atom.

\subsection{Molecular modeling}

\subsubsection{Geometry optimization}

Selected bond distances, angles and dihedral angles for the three forms reported in figure $2\left(\mathrm{RuO}_{3} \mathrm{~N}\right.$ tetrahedral form: form(a), $\mathrm{RuN}_{3} \mathrm{O}_{3}$ octahedral form: form(b), $\mathrm{N}_{3} \mathrm{O}$ tetrahedral form: form(c)) are listed in Table 1. The optimized structures of the studied complex show that the bond distances Ru1-N2 and Ru1-O6 increase in the order form $(c)<$ form(a)<form(b). The bond angles (N2-Ru1-O6) and (N2-Ru1N3) decrease in the following order: form $(c)>$ form(b)>form(a), while the bond angles (O5-Ru1-O7) and (O5-Ru1-N3) decrease in the order: form(a) $>$ form(b) $>$ form $(c)$.

The dihedral angles (O6-Ru1-N2-H10) and (O6-Ru1-O5-C18) decrease in the following order: form(c) $>$ form(a) $>$ form(b), whereas the dihedral angles (N2-Ru1-O5-C18) and (N2-Ru1-O6-C28) decrease in the order: form(c) $>$ form(b) $>$ form(a).

\subsubsection{Magnetic measurements}

Energies, calculated Mulliken charges and the dipole moments for the three forms of the $\mathrm{Ru}(\mathrm{III})$ complex are presented in Table 2. The values of minimized energy of the three forms of the complex 
show that the form(c) $\left(\mathrm{RuN}_{3} \mathrm{O}\right)$ has a low energy, indicating that this structure is more stable compared to the other forms.

The dipole moment is the indicator of the symmetry. If the system is symmetric, the dipole moment is equal to zero, and the charges distributed on each atom are equal to each other.

For the studied complex, the dipole moment differs from the zero. It increases while passing from the form(c) $(6.2 \mathrm{D})$ to the form(b) $(8.79 \mathrm{D})$ and the form(a) $(8.85 \mathrm{D})$. The form(c) has a small dipole moment, confirming the stability of this structure compared to the other molecular geometry forms.

\subsubsection{HOMO and LUMO}

Some parameters such as highest occupied molecular orbitals (HOMO) and lowest unoccupied molecular orbitals (LUMO) and energy gap of the complexes have been calculated (Table 2).

Fig. 3 shows the frontier orbitals shape. The HOMO density of octahedral form of the complex is distributed over the metallic element (Ru1), oxygen (O5, O6), nitrogen (N3, N4) atoms and the phenyl groups. For the form $\mathrm{RuO}_{3} \mathrm{~N}$, the HOMO is localized also on the metal (Ru1) but with a weak contribution, and on the oxygen $(\mathrm{O} 6, \mathrm{O} 7)$ with a great contribution. Concerning the form $\mathrm{RuN}_{3} \mathrm{O}$, the HOMO density is localized over the pyridine ring, and extends to the nitrogen atom (N2) of the amine function.

For the LUMO level we observed a trend on the three forms of the complex whose the energy is decreasing from -0.17088 a.u. for the form $\mathrm{RuN}_{3} \mathrm{O}$ to -0.17331 a.u. for $\mathrm{RuN}_{3} \mathrm{O}_{3}$ to -0.17443 a.u. for $\mathrm{RuO}_{3} \mathrm{~N}$.

The gap energy values (form $\mathrm{RuN}_{3} \mathrm{O}_{3}$ : $0.48 \mathrm{eV}$; form $\mathrm{RuO}_{3} \mathrm{~N}$ : $0.40 \mathrm{eV}$; form $\mathrm{RuN}_{3} \mathrm{O}$ : $0.54 \mathrm{eV}$ ) show that the form $\mathrm{RuN}_{3} \mathrm{O}$ has largest gap compared to the other forms, indicating the most stable structure. 


\subsection{Electrochemical study of Ru(III)-BSAP-PLA complex}

The electrochemical behaviors of different compounds have been studied in DMSO and $\mathrm{NBu}_{4} \mathrm{PF}_{6}$ solution $(0.1 \mathrm{M})$ by cyclic voltammetry $(\mathrm{CV})$ in 1.5 to $-1.8 \mathrm{~V}$ potential range.

To determine the electron transfer processes of the ruthenium complex and to avoid misinterpretation due to confusion between the redox processes of ligands, metallic salt and ruthenium complex, it is necessary to study the electrochemical behaviors of BSAP-PLA and Ru(III) alone.

The voltammogram of $\mathrm{Ru}(\mathrm{III})$ complex shows a cyclic oxidation-reduction process that does not change after repeated of 20 scans, indicating the stability of the electrochemical process.

Comparison of the cyclic voltammogram of $\mathrm{Ru}(\mathrm{III})$ complex with those of ligand and metal, the oxidation waves in 0.40 to $0.90 \mathrm{~V}$ and the reduction waves in -0.20 to $0.36 \mathrm{~V}$ potential ranges could be assigned to the metal ionization.

The cyclic voltammogram of BSAP-PLA shows one redox couple Red/Ox (Fig. S3). The reduction and oxidation potential values are $\mathrm{Ep}_{\mathrm{c}}=-1.64 \mathrm{~V}$ and $\mathrm{Ep}_{\mathrm{a}}=1.28 \mathrm{~V}$, respectively. These potentials were attributed to the reduction and oxidation of $\mathrm{OH}$ phenolic group.

The cyclic voltammogram of Ru(III)-BSAP-PLA complex reported in figure S3 shows two oxidation processes. The oxidation wave at $\mathrm{Epa}_{1}=0.86 \mathrm{~V}$ is attributed to the oxidation of $\mathrm{Ru}(\mathrm{II})$ to $\mathrm{Ru}(\mathrm{III})$. The $\mathrm{Ep}_{\mathrm{a}}$ of this couple was located around $0.80 \mathrm{~V}$ in the complexes using ITO electrode modified by Nafion containing $\left[\mathrm{Ru}(\mathrm{L})(\right.$ totpy $\left.)\left(\mathrm{OH}_{2}\right)\right]\left(\mathrm{PF}_{6}\right)_{2} \quad$ [36] and porous carbon felt electrode containing cis-aqua dimethyl bipyridyl triphenylphophine ruthenium(II) diphenolate [37].

The oxidation peak at $\mathrm{Epa}_{2}=0.43 \mathrm{~V}$ is assigned to the oxidation of $\mathrm{Ru}(\mathrm{I})$ to $\mathrm{Ru}(\mathrm{II})$. While, The reduction of $\mathrm{Ru}(\mathrm{III})$ to $\mathrm{Ru}(\mathrm{II})$ and $\mathrm{Ru}(\mathrm{II})$ to $\mathrm{Ru}(\mathrm{I})$ appeared at 0.15 and $-0.10 \mathrm{~V}$, respectively.

The reduction and oxidation waves observed at -1.34 and $-1.07 \mathrm{~V}$ were attributed respectively to the reduction and oxidation of imine groups. Whereas, the oxidation process at positive potential range 
shown in the ligand voltammograms did not appeared in the Ru(III)-BSAP-PLA voltammogram, this is due to the disappearance of phenolic group in the complex molecule. These results show that the ligands are bounded to the metal ion.

\subsection{SEM-EDS characterization of G/Ru(III)-BSAP-PLA composite material}

Scanning electron microscopy coupled with energy dispersive spectroscopy was used for surface and morphology study, to evaluate particle size and microchemical analysis of the $\mathrm{G} / \mathrm{Ru}(\mathrm{III})$ complex composite material. SEM photograph and EDS analysis of the synthesized composite material are illustrated in Fig. 4.

From the SEM photograph, we noted that there is a uniform matrix of the prepared composite material (G/Ru(III)-BSAP-PLA), indicating that G/Ru(III)-BSAP-PLA is homogeneous phase material and the ternary $\mathrm{Ru}(\mathrm{III})$ complex was homogeneously distributed on the graphite support. This is an advantage for the catalytic activity of the complex.

The in situ analysis of the sample shows that the $\mathrm{Ru}$ element is showing distribution having a significant concentration.

\subsection{Optimization of experimental parameters}

\subsubsection{Stability and scan rate effect studies}

To study the stability of the modified cavity microelectrode in neutral medium $\left(\mathrm{NaH}_{2} \mathrm{PO}_{4} / \mathrm{Na}_{2} \mathrm{HPO}_{4}\right.$; $\mathrm{pH}=7$ ), ten successive voltammograms were performed using CME (Fig. 5) modified with G/Ru(III)BSAP-PLA composite material (Fig.6). The results showed that the CME/G/Ru(III)-BSAP-PLA modified electrode exhibit a well-defined cyclic voltammograms after scanning the potential between 0.4 and $1 \mathrm{~V}$ versus $\mathrm{Ag} / \mathrm{AgCl}$ reference electrode for the ten cycles (Fig. 6a). In the same potential interval, the cathodic and anodic sweep leads to voltammograms perfectly superimposed, indicating a 
reproducible current response of $\mathrm{CME}$ modified with $\mathrm{G} / \mathrm{Ru}(\mathrm{III})$-BSAP-PLA due to conservation of the total mass of the product in the cavity of microelectrode.

Fig. $6 \mathrm{~b}$ compares the cyclic voltammograms of graphite and G/Ru(III)-BSAP-PLA in phosphate buffer solution ( $\mathrm{pH}$ 7.0). The cavity microelectrode containing $\mathrm{G} / \mathrm{Ru}(\mathrm{III})-\mathrm{BSAP}-\mathrm{PLA}$ is associated with large current response, indicating the enhanced response of the CME modified with G/Ru(III)-BSAP-PLA compared to the CME/Graphite electrode.

The cyclic voltammogram of the $\mathrm{CME} / \mathrm{G} / \mathrm{Ru}(\mathrm{III})$-BSAP-PLA electrode exhibit one reversible redox wave corresponding to the $\mathrm{Ru}(\mathrm{III}) / \mathrm{Ru}(\mathrm{II})$ couple. The determined oxidation and reduction peak currents are $i_{p a}=0.442 \times 10^{-6} \mathrm{~A} \quad\left(E_{p a}=-0.042 \mathrm{~V}\right)$ and $i_{p c}=-0.234 \times 10^{-6} \mathrm{~A} \quad\left(E_{p c}=-0.088 \mathrm{~V}\right)$, respectively.

\subsubsection{Electro-oxidation behavior of nitrite on different electrodes}

To study the electro-oxidation behavior of nitrite on CME/Graphite and CME/G/Ru(III)-BSAP-PLA modified electrodes, the cyclic voltammograms were recorded in the phosphate buffer solution containing $1.99 \times 10^{-5} \mathrm{M}$ of nitrite (Fig. 7). The results show an oxidation peak current around $0.67 \mathrm{~V}$ $(i=0.022 \mu A)$ and $0.84 \mathrm{~V}(i=0.14 \mu A)$ with $\mathrm{CME} /$ Graphite and CME/G/Ru(III)-BSAP-PLA, respectively, assigning to the oxidation of $\mathrm{NO}_{2}^{-}$to $\mathrm{NO}_{3}{ }^{-}$.

The determined oxidation peak current of nitrite on $\mathrm{CME} / \mathrm{G} / \mathrm{Ru}(\mathrm{III})-\mathrm{BSAP}-\mathrm{PLA}$ modified electrode is increased compared with CME/Graphite, indicating an effective electro-oxidation of $\mathrm{NO}_{2}{ }^{-}$on the modified CME electrode in the presence of the $\mathrm{Ru}(\mathrm{III})$-BSAP-PLA complex witch is considered as an electron mediator on the surface of $\mathrm{CME} / \mathrm{G} / \mathrm{Ru}(\mathrm{III})$-BSAP-PLA electrode. These results indicate the main electrocatalytic role of $\mathrm{Ru}(\mathrm{III})$ complex to promote the oxidation process of $\mathrm{NO}_{2}{ }^{-}$. 


\subsubsection{Effect of varying scan rate on electro-oxidation of nitrite}

The voltammograms obtained using CME modified with G/Ru(III)-BSAP-PLA complex versus scan rates in the absence of nitrite are shown in figure $\mathrm{S} 4$. The repetitive cyclic voltammograms at various scan rates are observed with no fluctuation in the anodic and cathodic peak currents of the complex, indicating the electroactivity and stability of $\mathrm{G} / \mathrm{Ru}(\mathrm{III})$-BSAP-PLA composite material in the cavity of microelectrode.

The transport characteristics of the $\mathrm{CME} / \mathrm{G} / \mathrm{Ru}(\mathrm{III})-\mathrm{BSAP}-\mathrm{PLA}$ electrode were studied by cyclic voltammetry method with different scan rates $(5-100 \mathrm{mV} / \mathrm{s})$ in buffer phosphate solution containing $1.59 \times 10^{-4} \mathrm{M}$ nitrite (Fig. 8a). The voltammograms showed that the oxidation peak current increases with increasing scan rate, and the low positive shift in peak potential position $\left(E_{p a}\right)$ with the scan rate indicating that the electro-oxidation process of nitrite is irreversible.

Reporting current vs. square root of scan rate (Fig. 8b), two linear regression equations $i_{p a}=0.0473 \times v^{1 / 2}+0.5955\left(R^{2}=0.984\right)$ and $i_{p a}=0.0864 \times v^{1 / 2}+0.3728\left(R^{2}=0.988\right)$ were obtained for scan rate ranging from 5 to $40 \mathrm{mV} / \mathrm{s}$ and 40 to $100 \mathrm{mV} / \mathrm{s}$, respectively, indicating that the kinetic of the overall process is not totally controlled by diffusion process but it also controlled by adsorption.

Referring to the Tafel equation defining a totally irreversible electrochemical process [38]:

$E_{p}=\frac{a}{2} \log v+b \quad\left(b=\right.$ constant, $\left.a=\frac{2.303 R T}{(1-\alpha) n F}\right)$

$E_{p a}$ vs. $\log v$ (not shown here) showed a linear regression equation of $E_{p a}=0.087 \log v+0.799$ and a correlation coefficient $R^{2}=0.998$.

Assuming that the number of transferred electrons for oxidation of nitrite is $n=2$, the electron transfer coefficient determined using Tafel slope was $a=0.83$. This value indicates a better electrocatalytic mechanism for oxidation of nitrite in the presence of the $\mathrm{Ru}(\mathrm{III})$-BSAP-PLA complex compared with 
oxidation of nitrite at other published electrodes such as Adge plane pyrolytic graphite electrode-Single walled carbon nanotubes-cobalt modified electrode (EPPGE-SWCNT-Co: $a=0.72)[21]$ and cobalt phthalocyanide modified electrode $(a=0.73)$ [39].

\subsubsection{Effect of $p H$}

The voltammetric current response of the CME/G/Ru(III)-BSAP-PLA modified electrode was investigated with different $\mathrm{pH}$ values in the presence of $1.59 \times 10^{-4} \mathrm{M} \mathrm{NO}_{2}^{-}$(Fig. 9a). The results revealed that the current decreases over a range of $\mathrm{pH}$ values from $\mathrm{pH} 2.22$ to 8.02.

Over the acidity range of $\mathrm{pH} 2-7$, the positive charge of the Ru(III)-BSAP-PLA decreases resulting the decrease in the oxidation peak current of nitrite.

According to the figure $9 \mathrm{a}$, the potential shifts slightly to lower values from $\mathrm{pH} 2.22$ to 8.02 , and the maximum oxidation peak current was given at $\mathrm{pH}=2.22$.

$\mathrm{pH}$ solution was chosen around 7 for all experiments because the potential of nitrite oxidation peak is low at this $\mathrm{pH}$ value which corresponds to the optimum $\mathrm{pH}$ value of water.

According to these results, the oxidation peak current and potential indicate that the $\mathrm{CME} / \mathrm{G} / \mathrm{Ru}(\mathrm{III})$ BSAP-PLA modified electrode responds effectively to the oxidation of nitrite at different $\mathrm{pH}$ values.

\subsection{Electrochemical reactivity}

\subsubsection{Chronocoulometry}

The Chronocoulometry was used as main method to investigate the oxidation process of nitrite ions at CME/Graphite and CME/G/Ru(III)-BSAP-PLA modified electrodes. The plots of charge $(Q)$ versus time $(t)$ and square root of time $\left(t^{1 / 2}\right)$ were reported in figure 10.

The linear relationship between $Q$ and $t^{1 / 2}$ could be expressed according the following formula [40]: 


$$
Q(t)=\frac{2 n F A c D^{1 / 2} t^{1 / 2}}{\pi^{1 / 2}}+Q_{d l}+Q_{a d s}
$$

Where $n$ is the number of transferred electrons, $F$ is Faraday constant, $A$ is surface area of working electrode, $c$ is concentration of substrate, $D$ is diffusion coefficient, $Q_{d l}$ is double layer charge, $Q_{a d s}$ is Faradic charge.

$Q_{a d s}$ was obtained by the difference of two intercepts of the plot of $Q$ vs. $t^{1 / 2}$ for curves in the absence and presence of nitrite.

The surface coverage $(\Gamma)$ can be expressed according to the Faraday law:

$$
Q_{a d s}=n F A \Gamma
$$

According to the figure $10 \mathrm{~b}$, the determined equations were reported below:

$$
Q=-4.222 \times 10^{-5} \mathrm{t}^{1 / 2}-2.670 \times 10^{-5}\left(\mathrm{CME} / \mathrm{G} / \mathrm{Ru}(\mathrm{III})-\mathrm{BSAP}-\mathrm{PLA}: Q_{a d s}=13.25 \mu C\right. \text {, }
$$$$
\left.D=7.768 \times 10^{-12} \mathrm{~cm}^{2} \mathrm{~s}^{-1}, \Gamma=0.874 \times 10^{-6} \mathrm{~mol} \mathrm{~cm} \mathrm{~cm}^{-2}, R^{2}=0.998\right), Q=-1.079 \times 10^{-5} \mathrm{t}^{1 / 2}-6.906 \times 10^{-7}
$$

(CME/Graphite: $\left.Q_{a d s}=9.71 \mu C, D=5.074 \times 10^{-13} \mathrm{~cm}^{2} \mathrm{~s}^{-1}, \Gamma=0.654 \times 10^{-6} \mathrm{~mol} \mathrm{~cm}^{-2}, R^{2}=0.998\right)$.

The Faradic charge $\left(Q_{a d s}\right) \mathrm{NO}_{2}{ }^{-}$found with $\mathrm{CME} / \mathrm{G} / \mathrm{Ru}(\mathrm{III})$-BSAP-PLA modified electrode is higher than the determined with CME/Graphite. This may be explained by the fact that the Ru(III)-BSAPPLA complex attract large amount of $\mathrm{NO}_{2}^{-}$ions involving high Faradic charge and high surface coverage.

\subsubsection{Chronoamperometry}

The chronoamperometry technique was used to evaluate the rate of electrocatalyzed oxidation of nitrites at $\mathrm{CME} / \mathrm{G} / \mathrm{Ru}(\mathrm{III})$-BSAP-PLA modified electrode. Fig. 11 shows the current $v s$. time curves by 
setting the potential of $\mathrm{CME} / \mathrm{G} / \mathrm{Ru}(\mathrm{III})$-BSAP-PLA at $920 \mathrm{mV}$ in the absence and presence of nitrite ions. In range times of 0 to $20 \mathrm{~s}$, the chronoamperograms show larger electrocatalytic currents in the presence of nitrite. This may be explained by the high speed of the electrocatalyzed oxidation of nitrite ions.

The chemical reaction between $\mathrm{NO}_{2}{ }^{-}$and redox sites of the $\mathrm{Ru}(\mathrm{III})$-BSAP-PLA complex ends after 10s because between 10 and 20s the current remains constant.

3.9. Electrochemical behavior of CME modified with G/Ru(III)-BSAP-PLA composite material versus nitrite concentrations

The electrochemical behavior of the cavity microelectrode modified with $\mathrm{G} / \mathrm{Ru}(\mathrm{III})$-BSAP-PLA composite material without addition of nitrite showed an oxidation $\left(\mathrm{E}_{\mathrm{pa}}=0.70 \mathrm{~V}, \mathrm{i}_{\mathrm{a}}=1.17 \mathrm{nA}\right)$ and reduction peak $\left(\mathrm{E}_{\mathrm{pa}}=-0.11 \mathrm{~V}, \mathrm{i}_{\mathrm{a}}=-92.50 \mathrm{nA}\right)$ corresponding respectively to $\mathrm{Ru}(\mathrm{II}) / \mathrm{Ru}(\mathrm{III})$ and $\mathrm{Ru}(\mathrm{III}) /$ $\mathrm{Ru}(\mathrm{II})$ couples. The low oxidation peak current around $0.7 \mathrm{~V}$ must be assigned to $\mathrm{Ru}(\mathrm{III}) / \mathrm{Ru}(\mathrm{IV})$ couple.

After adding $\mathrm{NO}_{2}^{-}$in the phosphate buffer solution (Fig. 12a), the response of the CME/G/Ru(III)BSAP-PLA electrode shows that the oxidation peak current around $0.8 \mathrm{~V}$ increases with increasing nitrite concentration. The electrocatalytic processes are expressed by the following reactions:

$\mathrm{Ru}^{\mathrm{III}}-\mathrm{BSAP}-\mathrm{PLA} \leftrightarrow\left(\mathrm{Ru}^{\mathrm{IV}}-\mathrm{BSAP}-\mathrm{PLA}\right)^{+}+\mathrm{e}^{-}$

$\mathrm{NO}_{2}^{-}+\left(\mathrm{Ru}^{\mathrm{IV}}-\mathrm{BSAP}-\mathrm{PLA}\right)^{+} \leftrightarrow \mathrm{Ru}^{\mathrm{III}}-\mathrm{BSAP}-\mathrm{PLA}+\mathrm{NO}_{2}$

Based on the literature [41], $\mathrm{NO}_{2}$ gives nitrite and nitrate ions by the following reaction:

$2 \mathrm{NO}_{2}+\mathrm{H}_{2} \mathrm{O} \leftrightarrow \mathrm{NO}_{2}^{-}+\mathrm{NO}_{3}^{-}+2 \mathrm{H}^{+}$.

Combining (1), (2) and (3), the overall catalytic mechanism is given in the following reaction:

$\mathrm{NO}_{2}{ }^{-}+2\left(\mathrm{Ru}^{\mathrm{IV}}-\mathrm{BSAP}-\mathrm{PLA}\right)^{+}+\mathrm{H}_{2} \mathrm{O} \leftrightarrow \mathrm{NO}_{3}^{-}+2 \mathrm{H}^{+}+2 \mathrm{Ru}^{\mathrm{III}}-$ BSAP-PLA. 
The electrochemical behavior of CME modified with G/Ru(III)-BSAP-PLA towards the nitrite ions shows an anodic oxidation wave at $0.86 \mathrm{~V}$ that substantially increases with increasing nitrite concentration. These results show that the modified CME really responds to variation of nitrite concentration and the Ru(III)-BSAP-PLA complex catalyses the oxidation of nitrites.

Based on the curves current vs. potential, the oxidation and reduction currents from $\mathrm{CME} / \mathrm{G} / \mathrm{Ru}(\mathrm{III})$ BSAP-PLA electrode versus concentration of nitrite ions are presented in figure $12 \mathrm{~b}$. The intensity of oxidation current increases linearly with increasing of nitrite concentration in the range of 0 to $1.59 \times 10^{-4} \mathrm{M}$ (The linear regression equation: $i=5800.87 C-0.066, R^{2}=0.992$ ). The measurements performed using $\mathrm{CME} / \mathrm{G} / \mathrm{Ru}(\mathrm{III})$-BSAP-PLA electrode gave highest sensitivity and good linearity corresponding to correlation coefficient $\mathrm{R}^{2}=0.992$.

The electrochemical behavior of the modified electrode towards nitrite concentrations showed that the system CME/G/Ru(III)-BSAP-PLA can be considered as a detector of $\mathrm{NO}_{2}{ }^{-}$. The limit of detection $(L O D)$ was calculated using the following equation:

$$
L O D=3 s / m
$$

Where $s$ is the standard deviation of the blank signal and $m$ is the slope of the calibration curve.

The sensitivity and limit of detection of CME modified with G/Ru(III)-BSAP-PLA composite material are $5.80 \mu \mathrm{A} . \mathrm{mM}^{-1}$ and $1.81 \mu \mathrm{M}$, respectively.

Comparison of the obtained limit detection of our modified electrode with those found in the literature around nitrite concentrations range of 0 to $159 \mu \mathrm{M}$ and $\mathrm{pH}=7$ (Table 2), LOD calculated for $\mathrm{CME} / \mathrm{G} / \mathrm{Ru}(\mathrm{III})-\mathrm{BSAP}-\mathrm{PLA}$ electrode was much lower than the limit detection of nitrite ions determined using different modified electrodes [21, 42, 43] and CME/G/Ru(III)-BSAP-PLA electrode exhibited much higher current response sensitivity towards nitrite oxidation around $0.86 \mathrm{~V}$, which is 
corresponding to the conversion of $\mathrm{NO}_{2}{ }^{-}$to $\mathrm{NO}_{3}{ }^{-}$. It can be explained by the synergetic effect of $\mathrm{Ru}(\mathrm{III})$-BSAP-PLA complex in electrocatalytic oxidation of nitrite ions.

\section{Conclusion}

In this work, an electrochemical sensor for detection of nitrite ions was prepared by using the cavity microelectrode $(\mathrm{CME})$ modified with graphite-ternary $\mathrm{Ru}(\mathrm{III})$ complex composite material $(\mathrm{G} / \mathrm{Ru}(\mathrm{III})$ BSAP-PLA).

The characterization of $\mathrm{Ru}(\mathrm{III})$-BSAP-PLA complex using different methods such as elemental analysis, FT-IR, UV-Visible, gHSQC and DFT suggests an tetrahedral environment around the ruthenium(III). SEM photograph revels that the ternary $\mathrm{Ru}(\mathrm{III})$-BSAP-PLA complex was homogeneously distributed on the graphite support.

The determined electron transfer coefficient $(a=0.83)$ indicates a better electrocatalytic mechanism for oxidation of nitrite in the presence of the $\mathrm{Ru}(\mathrm{III})$ complex compared with oxidation of nitrite at other modified electrodes published in the literature.

The chronocoulometry technique shows that the Faradic charge $\left(\mathrm{NO}_{2}{ }^{-}\right)$found with $\mathrm{CME} / \mathrm{G} / \mathrm{Ru}(\mathrm{III})$ BSAP-PLA modified electrode is higher than the determined with CME/Graphite. Additionally, the chronoamperometry technique reveals a high speed of the electrocatalyzed oxidation of nitrite ions in the presence of the $\mathrm{Ru}(\mathrm{III})$-BSAP-PLA complex.

Finally, the limit of detection of $\mathrm{CME} / \mathrm{G} / \mathrm{Ru}(\mathrm{III})-\mathrm{BSAP}-\mathrm{PLA}$ modified electrode $(L O D=1.81 \mu \mathrm{M})$ was much lower than $L O D$ determined using other published sensors around $\mathrm{pH}=7$ over nitrite concentration range of the same order of magnitude. 


\section{Acknowledgements}

The authors wish to express their gratude to Mrs. Ourida OUAMERALI of USTHB University (Laboratoire de Physico-Chimie Théorique et Chimie Informatique, Faculté de chimie, 16111, Algiers, Algeria) for DFT calculation of the ruthenium complex.

The French UMEC network of the CNRS is warmly acknowledged for providing the cavity microelectrode.

\section{References}

[1] J.B. Raoof, R. Ojani, M. Ramine, J. Solid State Electrochem. 13 (2012) 1311-1319.

[2] A. Kumaravel, M. Chandrasekaran, J. Electroanal. Chem. 650 (2011) 163-170.

[3] R. Ojani, J.B. Raoof, B. Norouzi, J Mater Sci. 44 (2009) 4095-4103.

[4] R. Ojani, J.B. Raoof, B. Norouzi, Electroanalysis 20 (2008) 1996-2002.

[5] K. Kalcher, I. Svancara, R. Metelka, K. Vytras, A. Walcarius, Heterogeneous carbon electrochemical sensors. In: C.A. Grimes, E.C. Dickey, and M.V. Pishko (Ed.), Encyclopedia of Sensors. American Scientific Publishers: Stevenson Ranch. 2006, pp. 283-430.

[6] H.E. Bakouri, J.M. Palacios-Santander, L. Cubillana-Aguilera, A. Ouassini, I. Naranjo-Rodríguez,

J.L. Hidalgo-Hidalgo de Cisneros, Chemosphere 60 (2005) 1565-1571.

[7] E. Barrado, J.I. Montequi, J. Medina, R. Pardo, F. Prieto, J. Electroanal. Chem. 441 (1998) 227235.

[8] A. Walcarius, L. Lamberts, J. Electroanal. Chem. 422 (1997) 77-89.

[9] S. Longchamp, H.N. Randriamahazaka, J.M. Nigretto, J. Electroanal. Chem. 412 (1996) 31-37. 
[10] K.H. Lubert, M. Wagner, R.M. Olk, Anal. Chim. Acta 336 (1996) 77-84.

[11] L. Gorton, Electroanalysis 7 (1995) 23-45.

[12] K. Kalcher, J.M. Kauffmann, J. Wang, I. Svancara, K. Vytras, C. Neuhold, Z. Yang, Electroanalysis 7 (1995) 5-22.

[13] J.B. Tommasino, B. Pomarede, D. Medus, D. Demonztauzon, P. Cassoux, P.L. Fabre, Mol. Cryst. Liqu. Cryst. Sci. Technol. Sect. A: 237 (1993) 445-456.

[14] C. Ait-Ramdane-Terbouche, A. Terbouche, S. Djebbar, D. Hauchard, Talanta 119 (2014) 214225.

[15] C. Shinn, A. Marco, L. Serrano, Chemosphere 92 (2013) 1154-1160.

[16] A. Terbouche, C. Ait-Ramdane-Terbouche, S. Djebbar, O. Benali-Baitich, D. Hauchard, Sens. Actuators B: 169 (2012) 297- 304.

[17] N.N. Zhu, Q. Xu, S. Li, H. Gao, Electrochem. Commun. 11 (2009) 2308-2311.

[18] X. Huang, Y.X. Li, Y.L. Chen, L. Wang, Sens. Actuators B: 134 (2008) 780-786.

[19] M. Guo, J. Chen, J. Li, B. Tao, S. Yao, Anal. Chim. Acta 532 (2005) 71-77.

[20] Y. Tian, J. Wang, Z. Wang, S. Wang, Synth. Met. 143 (2004) 309-313.

[21] S. Kakhki, E. Shams, M.M. Barsan, J. Electroanal. Chem. 704 (2013) 80-85.

[22] A.S. Adekunle, J. Pillay, K.I. Ozoemena, Electrochim. Acta 55 (2010) 4319-4327.

[23] C.Y. Lin, V.S. Vasantha, K.C. Ho, Sens. Actuators B: 140 (2009) 51-57.

[24] T.S. Liu, T.F. Kang, L.P. Lu, Y. Zhang, S.Y. Cheng, J. Electroanal. Chem. 632 (2009) 197-200.

[25] Q.P. Chen, S.Y. Ai, X.B. Zhu, H.S. Yin, Q. Ma, Y.Y. Qiu, Biosens. Bioelectron. 24 (2009) 29912996.

[26] M.A. Kamyabi, F. Aghajanloo, J. Electroanal. Chem. 614 (2008) 157-165.

[27] F. Xiao, L.Q. Liu, J. Li, Electroanalysis 20 (2008) 2047-2054.

[28] E.H. Seymour, N.S. Lawrence, M. Pandurangappa, R.G. Compton, Microchim. Acta 140 (2002) 
211-217.

[29] L.H. Larsen, L.R. Damgaard, T. Kjaer, T. Stenstrom, A. Lynggard-Jensen, P. Revsbech, Water Res. 34 (2000) 2458-2463.

[30] H. Gunasingham, C.B. Tan, Analyst 114 (1989) 695-698.

[31] P.E. Kruger, B. Moubaraki, G.D. Fallon, K.S. Murray, J. Chem. Soc., Dalton Trans. 5 (2000) 713 718.

[32] Y. Zhao, D.G. Truhlar, Theor. Chem. Acc. 120 (2008) 215-41.

[33] P.J. Hay, W.R. Wadt, J. Chem. Phys. 82 (1985) 270-283.

[34] M.J. Frisch, G.W. Trucks, H.B. Schlegel, G.E. Scuseria, M.A. Robb, J.R. Cheeseman, J.A.

Montgomery, T. Vreven, K.N. Kudin, J.C. Burant, J.M. Millam, S.S. Iyengar, J. Tomasi, V. Barone, B. Mennucci, M. Cossi, G. Scalmani, N. Rega, G.A. Petersson, H. Nakatsuji, M. Hada, M. Ehara, K. Toyota, R. Fukuda, J. Hasegawa, M. Ishida, T. Nakajima, Y. Honda, O. Kitao, H. Nakai, M. Klene, X. Li, J.E. Knox, H.P. Hratchian, J.B. Cross, C. Adamo, J. Jaramillo, R. Gomperts, R.E. Stratmann, O. Yazyev, A.J. Austin, R. Cammi, C. Pomelli, J.W. Ochterski, P.Y. Ayala, K. Morokuma, G.A. Voth, P. Salvador, J.J. Dannenberg, V.G. Zakrzewski, S. Dapprich, A.D. Daniels, M.C. Strain, O. Farkas, D.K. Malick, A.D. Rabuck, K. Raghavachari, J.B. Foresman, J.V. Ortiz, Q. Cui, A.G. Baboul, S. Clifford, J. Cioslowski, B. B. Stefanov, G. Liu, A. Liashenko, P. Piskorz, I. Komaromi, R.L. Martin, D.J. Fox, T. Keith, M.A. Al-Laham, C.Y. Peng, A. Nanayakkara, M. Challacombe, P.M.W. Gill, B. Johnson, W. Chen, M.W. Wong, C. Gonzalez, J.A. Pople, Gaussian 03, Revision A.1, Gaussian, Inc., Pittsburgh PA, 2003.

[35] A.Z. El-Sonbati, A.A. El-Bindary, A.F. Shoair, Spectrochim. Acta, Part A 58 (2002) 3003-3009. [36] E.M. Sussuchi, A.A. De Lima, W.F. De Giovani, Polyhedron 25 (2006) 1457-1463.

[37] J.R. Steter, J.O.S. Ponto’' lio, M.I.C.F. Costa, J.R. Romero, Polyhedron 26 (2007) 996-1000. [38] A.J. Bard, L.R. Faulkner, Electrochemical Methods. Fundamentals and Applications (second 
ed.), John Wiley and Sons, Hoboken, New Jersey, 2001.

[39] F. Matemadombo, T. Nyokong, Electrochim. Acta 52 (2007) 6856-6864.

[40] F. Anson, Anal. Chem. 36 (1964) 932-934.

[41] R. Guidelli, F. Pergola, G. Raspi, Anal Chem. 44 (1972) 745-755.

[42] P. Miao, M. Shen, L.M. Ning, G.F. Chen, Y.M. Yin, Anal. Bioanal. Chem. 399 (2011) 24072411.

[43] Q. Wang, D. Dong, N. Li, Bioelectrochemistry 54 (2001) 169-175. 


\section{List of Tables}

Table 1: Calculated structural parameters of the three forms for $\mathrm{Ru}(\mathrm{III})$ complex.

Table 2: Energetic properties, dipole moments, charge of Mullikan, energies of HOMO, LUMO orbitals and energy gap of the three forms of the ruthenium complex.

Table 3: Comparison of the performances of some different nitrite sensors around $\mathrm{pH}=7$.

\section{Figure captions}

Scheme 1. Structure of (a) 1,3-bis(salicylideneamino)propan-2-ol (BSAP) and (b) 3-Picolylamine (PLA) and reaction scheme for the synthesis of the ruthenium complex.

Figure 1. FTIR spectra of (a) PLA, (b) BSAP and (c) Ru(III)-BSAP-PLA complex.

Figure 2. Geometry forms of $\mathrm{Ru}(\mathrm{III})-\mathrm{BSAP}-\mathrm{PLA}$ complex: (a) $\mathrm{RuO}_{3} \mathrm{~N}$ tetrahedral form, (b) $\mathrm{RuN}_{3} \mathrm{O}_{3}$ octahedral form, (c) $\mathrm{RuN}_{3} \mathrm{O}$ tetrahedral form.

Figure 3. Frontier molecular orbitals for the three forms of Ru(III)-BSAP-PLA complex: (a) HOMO of $\mathrm{RuN}_{3} \mathrm{O}_{3}$ octahedral form, (b) LUMO of $\mathrm{RuN}_{3} \mathrm{O}_{3}$ octahedral form, (c) HOMO of $\mathrm{RuO}_{3} \mathrm{~N}$ tetrahedral form, (d) LUMO of $\mathrm{RuO}_{3} \mathrm{~N}$ tetrahedral form, (e) HOMO of $\mathrm{RuN}_{3} \mathrm{O}$ tetrahedral form, (f) LUMO of $\mathrm{RuN}_{3} \mathrm{O}$ tetrahedral form.

Figure 4. (a) SEM microphotograph and (b) EDS analysis of G/Ru(III)-BSAP-PLA composite material.

Figure 5. Scheme of the cavity microelectrode (CME).

Figure 6. (a) Cyclic voltammograms obtained using CME/Graphite and CME/G/Ru(III)-BSAP-PLA 
modified electrodes and (b) successive cyclic voltammograms performed using CME/G/ $\mathrm{Ru}(\mathrm{III})-\mathrm{BSAP}-\mathrm{PLA}$ in $0.1 \mathrm{M}$ phosphate buffer solution. Experimental conditions: Temperature $=25^{\circ} \mathrm{C}$; Scan rate $=20 \mathrm{mV} / \mathrm{s}$.

Figure 7. Cyclic voltammograms obtained using CME/Graphite and CME/G/Ru(III)-BSAP-PLA electrodes in $0.1 \mathrm{M}$ phosphate buffer solution containing $1.99 \times 10^{-5} \mathrm{M} \mathrm{NO}_{2}$. Experimental conditions: Temperature $=25^{\circ} \mathrm{C}$; Scan rate $=20 \mathrm{mV} / \mathrm{s}$.

Figure 8. (a) Cyclic voltammograms obtained using CME/G/Ru(III)-BSAP-PLA modified Electrode in $0.1 \mathrm{M} \mathrm{NaH}_{2} \mathrm{PO}_{4} / \mathrm{Na}_{2} \mathrm{HPO}_{4}(\mathrm{pH}=7)$ in the presence of $1.59 \times 10^{-4} \mathrm{M} \mathrm{NO}_{2}{ }^{-}$at different scan rates and (b) Linear relationship between the oxidation peak current and the square root of scan rate. Temperature $=25^{\circ} \mathrm{C}$.

Figure 9. (a) Cyclic voltammograms obtained with $\mathrm{CME} / \mathrm{G} / \mathrm{Ru}(\mathrm{III})-\mathrm{BSAP}-\mathrm{PLA}$ modified electrode in the presence of $1.59 \times 10^{-4} \mathrm{MNO}_{2}^{-}$at different $\mathrm{pH}$ and (b) Oxidation peak current vs. $\mathrm{pH}$. Experimental conditions: Temperature $=25^{\circ} \mathrm{C}$; Scan rate $=20 \mathrm{mV} / \mathrm{s}$.

Figure 10. Plots of (a) $Q$ vs. $t$, (b) $Q$ vs. $t^{1 / 2}$ for CME/Graphite and CME/G/Ru(III)-BSAP-PLA in $0.1 \mathrm{M} \mathrm{NaH}_{2} \mathrm{PO}_{4} / \mathrm{Na}_{2} \mathrm{HPO}_{4}(\mathrm{pH}=7)$ in the absence and the presence of $3.97 \times 10^{-4} \mathrm{M} \mathrm{NO}_{2}{ }^{-}$. Experimental conditions: Temperature $=25^{\circ} \mathrm{C}$; Measuring period $=0.2 \mathrm{~s}$.

Figure 11. Chronoamperograms obtained using CME/G/Ru(III)-BSAP-PLA modified electrodes in $0.1 \mathrm{M} \mathrm{NaH}_{2} \mathrm{PO}_{4} / \mathrm{Na}_{2} \mathrm{HPO}_{4}(\mathrm{pH}=7)$ in the absence and the presence of $6.14 \times 10^{-3} \mathrm{M} \mathrm{NO}_{2}^{-}$. Experimental conditions: Temperature $=25^{\circ} \mathrm{C}$; Measuring period $=0.2 \mathrm{~s}$.

Figure 12. (a) Cyclic voltammograms obtained with $\mathrm{CME} / \mathrm{G} / \mathrm{Ru}(\mathrm{III})-\mathrm{BSAP}-\mathrm{PLA}$ modified electrode in $0.1 \mathrm{M} \mathrm{NaH}_{2} \mathrm{PO}_{4} / \mathrm{Na}_{2} \mathrm{HPO}_{4}(\mathrm{pH}=7)$ at different concentrations of $\mathrm{NO}_{2}{ }^{-}(\mathrm{M})$ and (b) Linear relationship between the oxidation peak current and the concentration of nitrite. 
Experimental conditions: Temperature $=25^{\circ} \mathrm{C}$; Scan rate $=20 \mathrm{mV} / \mathrm{s}$.

Table 1: Calculated structural parameters of the three forms for $\mathrm{Ru}(\mathrm{III})$ complex.

\begin{tabular}{|c|c|c|c|}
\hline \multirow[t]{2}{*}{ Parameters } & \multicolumn{2}{|c|}{ Forms of the Ru complex } & \multirow[b]{2}{*}{ Form(c): $\mathrm{RuN}_{3} \mathrm{O}$} \\
\hline & Form(a): $\mathrm{RuO}_{3} \mathrm{~N}$ & Form(b & \\
\hline \multicolumn{4}{|l|}{ Bond length $\left(\mathrm{A}^{\circ}\right)$} \\
\hline Ru1-N2 & 2.900 & 3.671 & 2.206 \\
\hline Ru1:N3 & 2.067 & 2.071 & 2.033 \\
\hline Ru1:N4 & 2.170 & 1.989 & 2.195 \\
\hline $\mathrm{Ru} 1: 05$ & 1.948 & 2.002 & 3.236 \\
\hline Ru1-O6 & 2.024 & 2.021 & 2.231 \\
\hline $\mathrm{Ru} 1: 07$ & 2.029 & 2.004 & 2.081 \\
\hline \multicolumn{4}{|l|}{ Bond Angles $\left({ }^{\circ}\right)$} \\
\hline N2-Ru1-O6 & & 77.5 & 91.2 \\
\hline N2-Ru1-N3 & 99.1 & 99.9 & 104.9 \\
\hline N2-Ru1-N4 & 72.8 & 72.8 & 105.2 \\
\hline O5-Ru1-O6 & 89.6 & 88.2 & 127.0 \\
\hline O5-Ru1-O7 & 157.9 & 153.9 & 120.2 \\
\hline O5-Ru1-N3 & 88.8 & 87.2 & 64.3 \\
\hline O6-Ru1-O7 & 103.6 & 104.6 & 80.3 \\
\hline O6-Ru1-N4 & 87.2 & 89.7 & 80.0 \\
\hline N3-Ru1-N4 & 90.6 & 93.1 & 92.8 \\
\hline \multicolumn{4}{|l|}{ Dihedral angles $\left({ }^{\circ}\right)$} \\
\hline O5-Ru1-N2-H9 & -37.9 & -37.3 & -4.6 \\
\hline O6-Ru1-N2-H10 & -153.6 & -156.1 & 9.9 \\
\hline N3-Ru1-N2-H9 & 11.7 & -117.3 & -56.8 \\
\hline
\end{tabular}




\section{ACCEPTED MANUSCRIPT}

$\begin{array}{llll}\text { N2-Ru1-O5-C18 } & -90.5 & -88.5 & -60.6 \\ \text { O6-Ru1-O5-C18 } & -164.4 & -164.6 & -132.4 \\ \text { N2-Ru1-O6-C28 } & 52.9 & 53.1 & 53.6\end{array}$


Table 2. Energetic properties, dipole moments, charge of Mullikan, energies of HOMO, LUMO orbitals and energy gap of the three forms of the ruthenium complex.

\begin{tabular}{llll}
\hline Parameters & \multicolumn{3}{c}{ Forms of complex } \\
\cline { 2 - 4 } & Form(a): $\mathrm{RuO}_{3} \mathrm{~N}$ & Form(b): $\mathrm{RuN}_{3} \mathrm{O}_{3}$ & Form(c): $\mathrm{RuN}_{3} \mathrm{O}$ \\
\hline Relative energy $(\Delta \mathrm{E}: \mathrm{Kcal} / \mathrm{mol})$ & 271.14 & 269.82 & 283.63 \\
Dipole moment (Deby) & 8.79 & 8.85 & 6.10 \\
Charge of Mulliken & $\mathrm{Ru} 1: 0.691$ & $\mathrm{Ru} 1: 0.767$ & $\mathrm{Ru}: 0.393$ \\
& $\mathrm{~N} 2:-0.615$ & $\mathrm{~N} 2:-0.655$ & $\mathrm{~N} 2:-0.716$ \\
& $\mathrm{~N} 3:-0.264$ & $\mathrm{~N} 3:-0.266$ & $\mathrm{~N} 3:-0.293$ \\
& $\mathrm{~N} 4:-0.156$ & $\mathrm{~N} 4:-0.256$ & $\mathrm{~N} 4:-0.128$ \\
& $\mathrm{O} 5:-0.583$ & $\mathrm{O} 5:-0.530$ & $\mathrm{O} 5:-0.496$ \\
& $\mathrm{O} 6:-0.468$ & $\mathrm{O} 6:-0.442$ & $\mathrm{O} 6:-0.554$ \\
$\mathrm{HOMO}$ (a.u.) & $\mathrm{O} 7:-0.409$ & $\mathrm{O} 7:-0.407$ & $\mathrm{O} 7:-0.491$ \\
LUMO (a.u.) & -0.18976 & -0.18921 & -0.19099 \\
$\Delta \mathrm{E}$ (eV) & -0.17331 & -0.17443 & -0.17088 \\
\hline
\end{tabular}


Table 3. Comparison of the performances of some different nitrite sensors around $\mathrm{pH}=7$.

\begin{tabular}{lclcl}
\hline Electrode & $\mathrm{pH}$ & Linear range $(\mu \mathrm{M})$ & LOD $(\mu \mathrm{M})$ & Ref. \\
\hline EPPGE-SWCNT-Co & 7.4 & $0-189$ & 5.61 & Adekunle et al., 2010 \\
Au-penicillamine SAM & 6.8 & $20-800$ & 4.0 & Wang et al., 2001 \\
Pt NPs/Au electrode & 7.4 & $10-1000$ & 5.00 & Miao et al., 2011 \\
CME/GC-Ru(III)-BSAP-PLA & 7.0 & $0-159$ & 1.81 & Present work \\
\hline
\end{tabular}

EPPGE: Adge-plane pyrolytic graphite electrode; SWCNT: Single-walled carbon nanotubes; SAM: Self-assembled monolayer; NPs: Nanoparticles; CME: Cavity microelectrode; LOD: Limit of detection. 


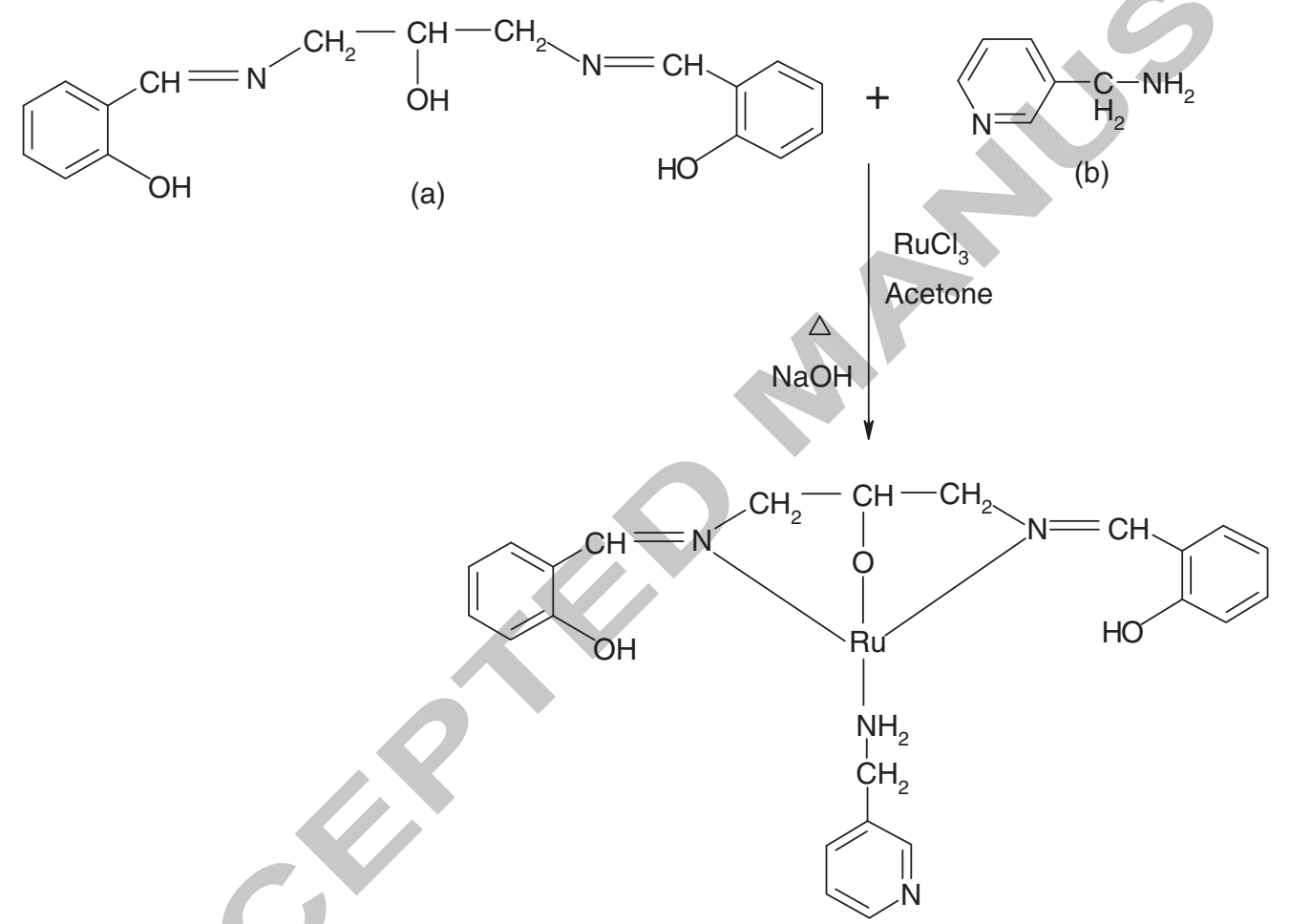

Scheme 1. 


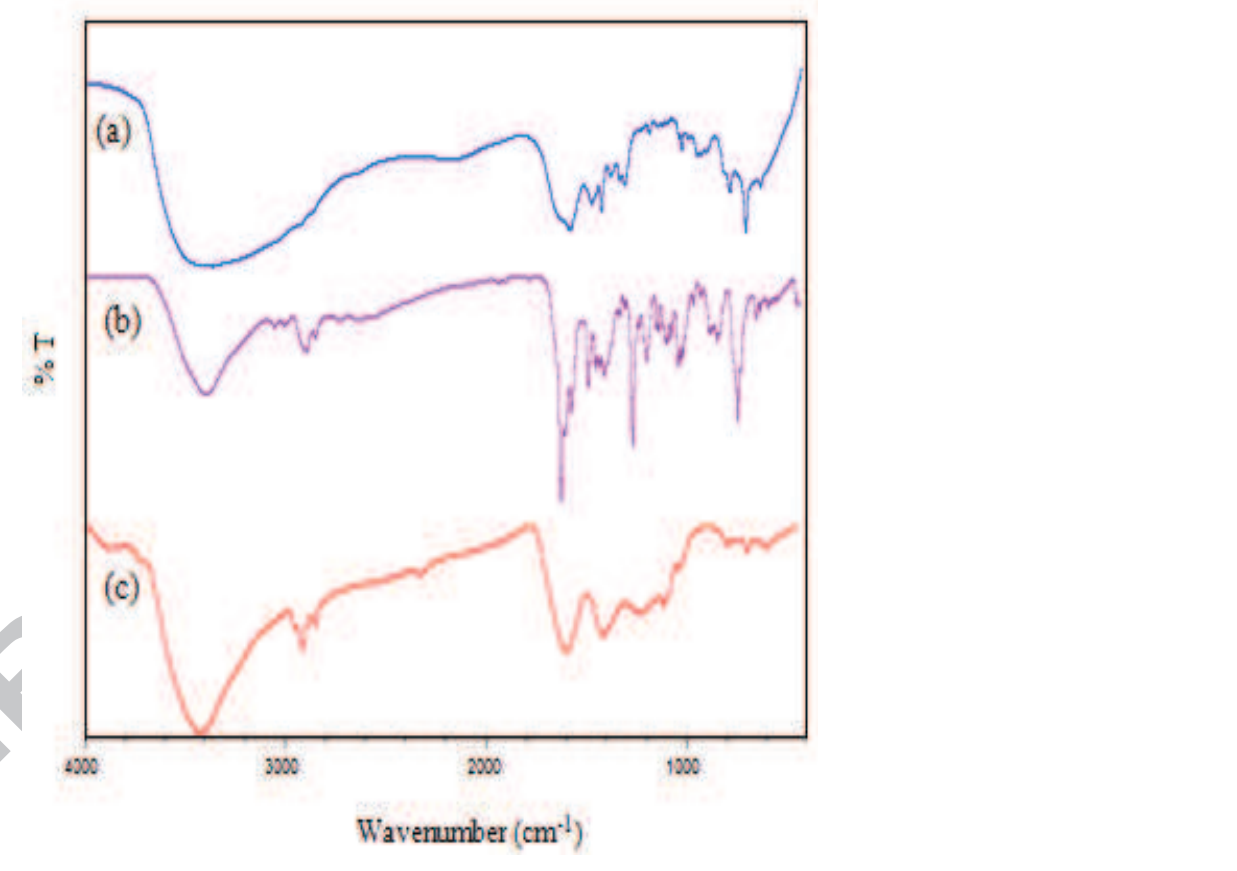

Figure 1. 


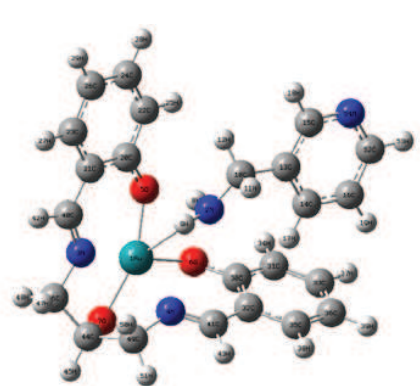

(a)

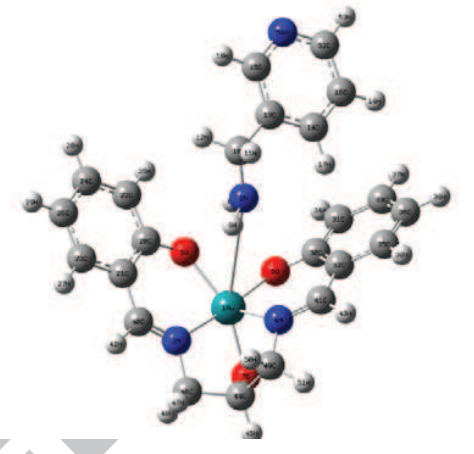

(b)

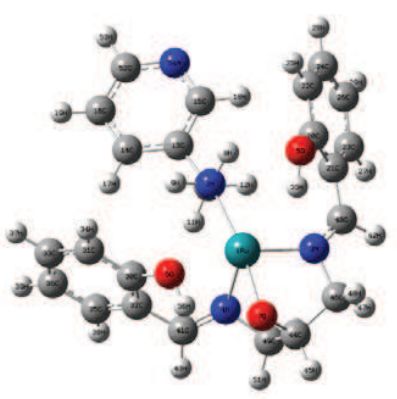

(c)

Figure 2. 


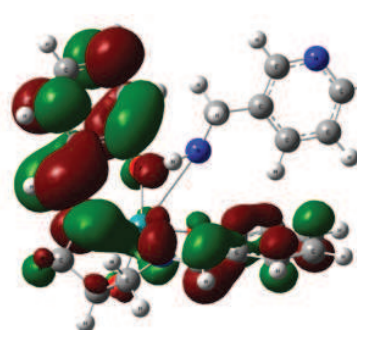

(a)

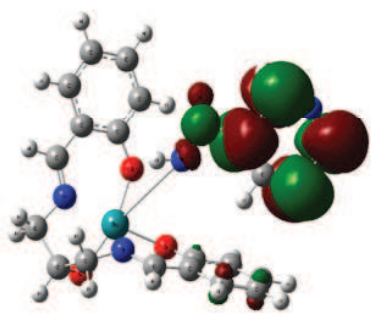

(d)

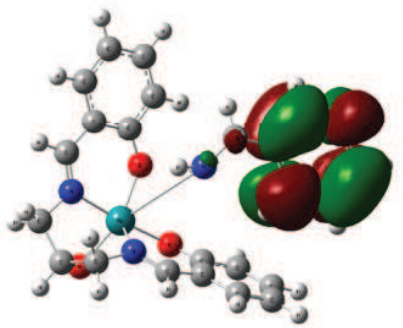

(b)

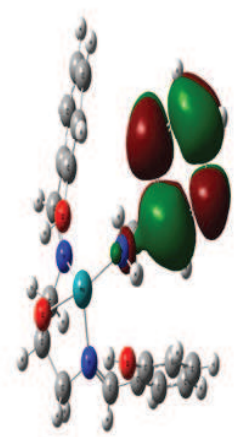

(e)

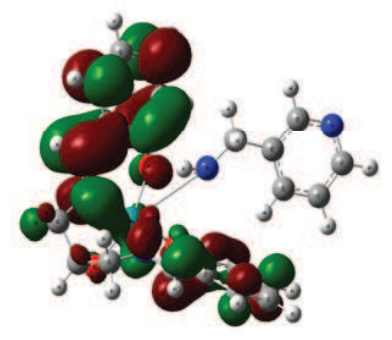

(c)

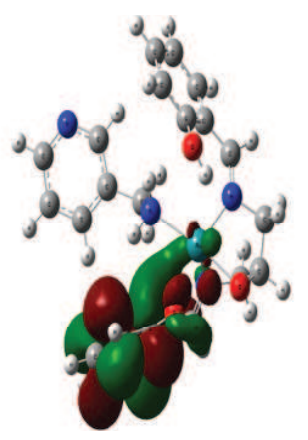

(f)

Figure 3. 

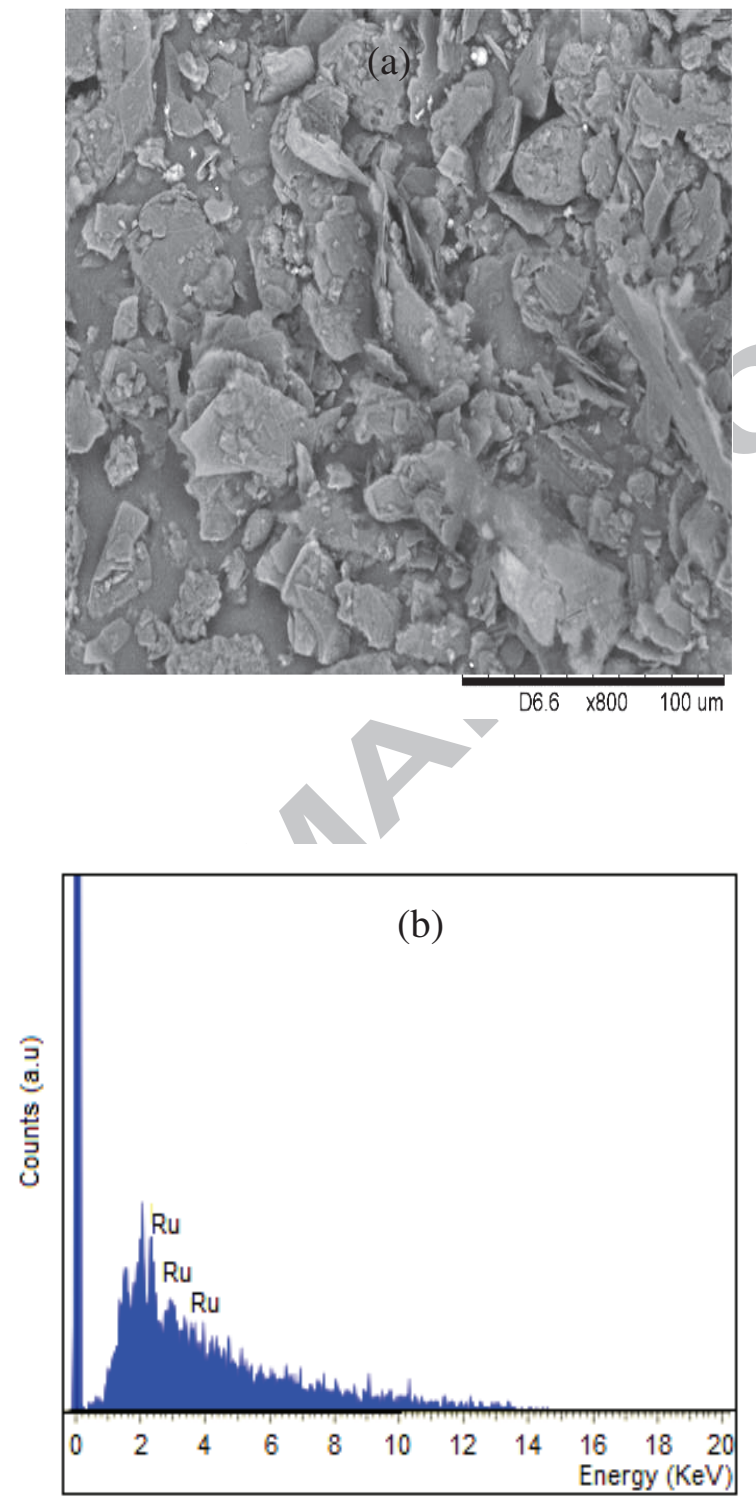

Figure 4. 


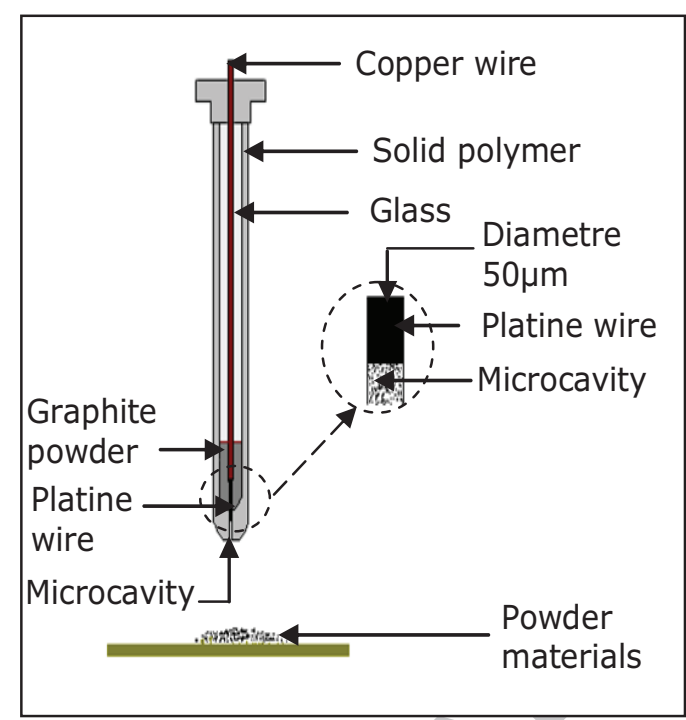

Figure 5. 


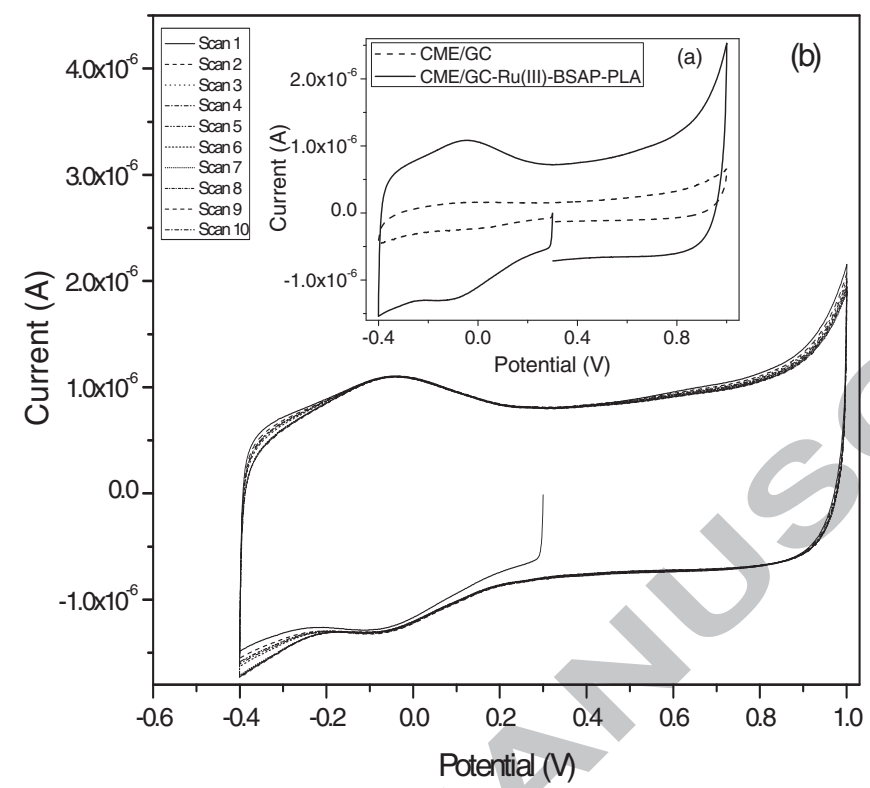

Figure 6. 


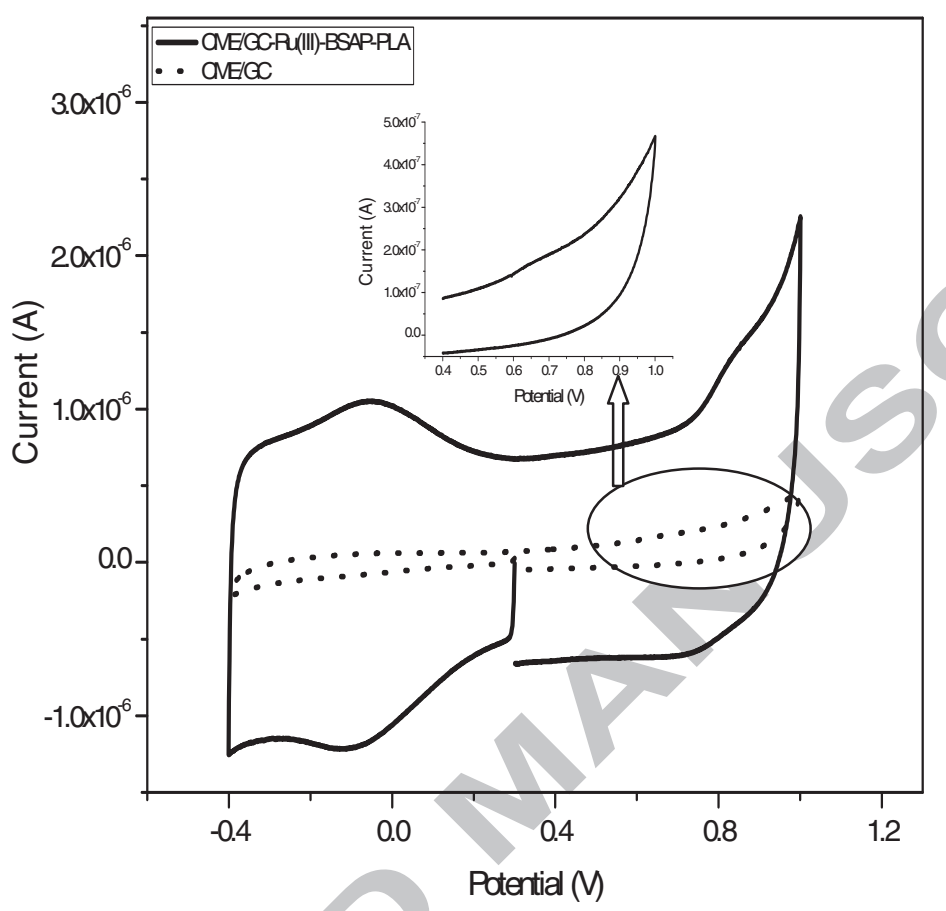

Figure 7. 


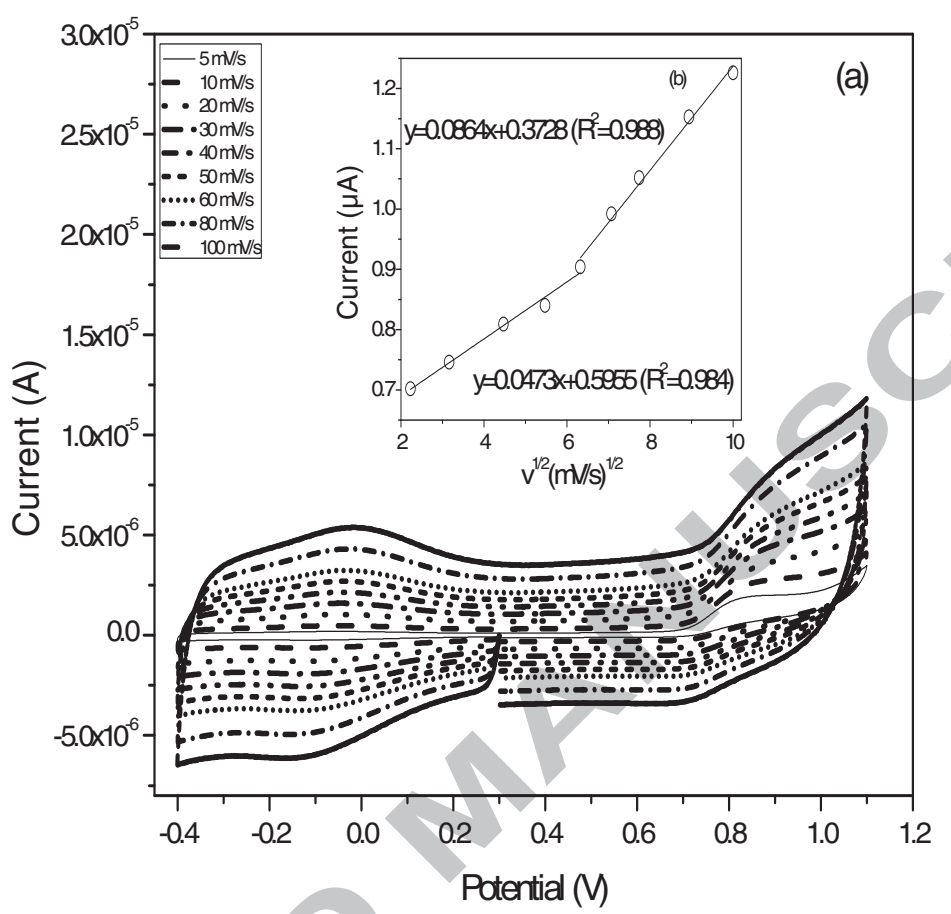

Figure 8. 


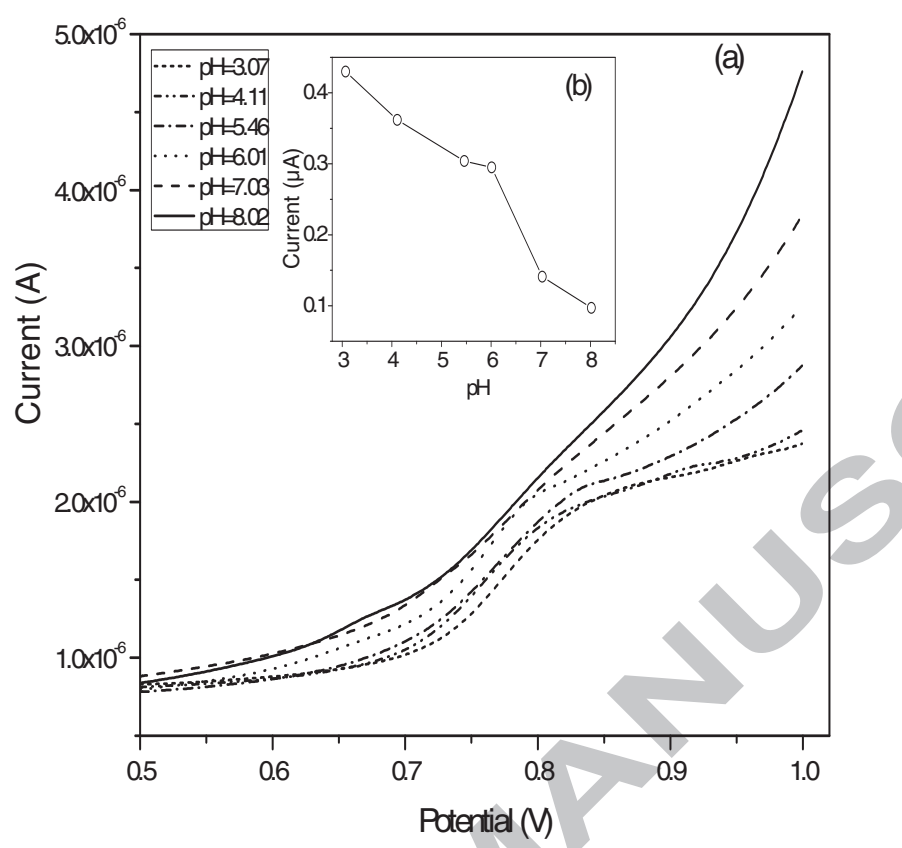

Figure 9. 

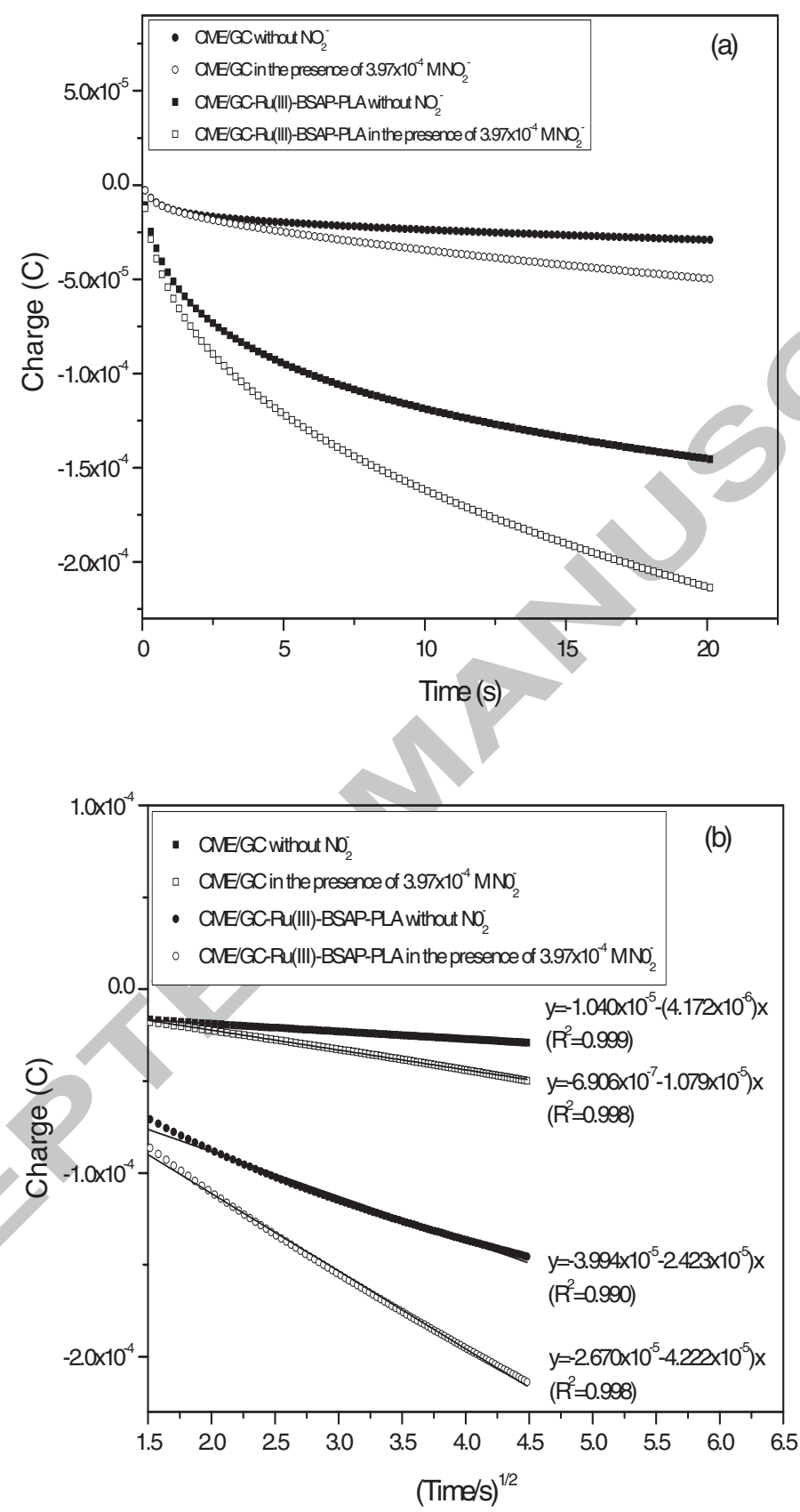

Figure 10. 


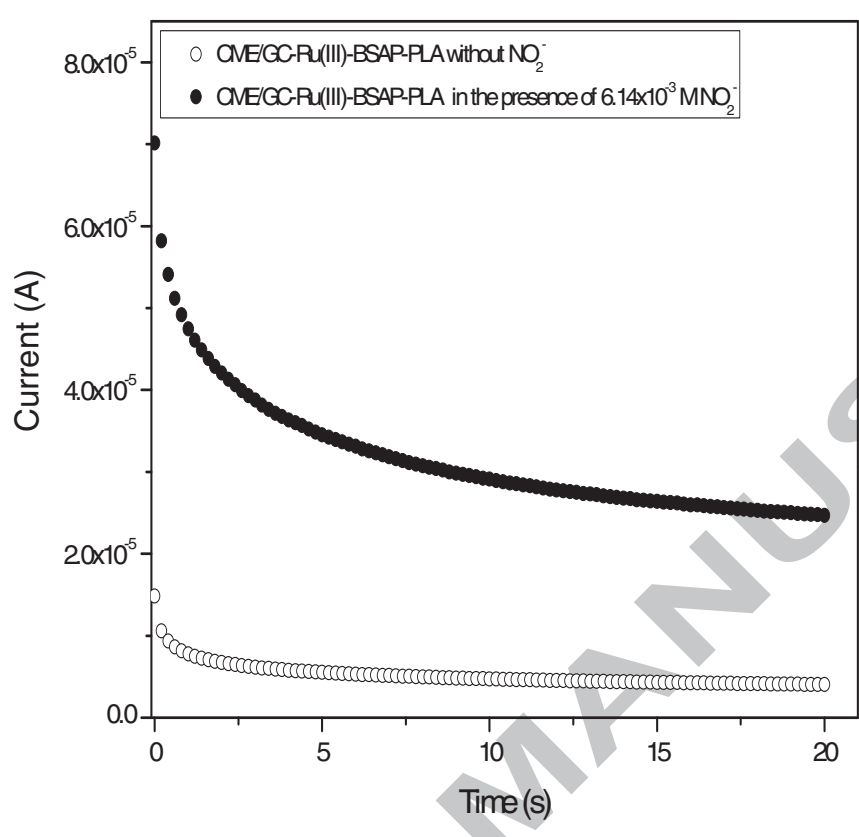

Figure 11. 


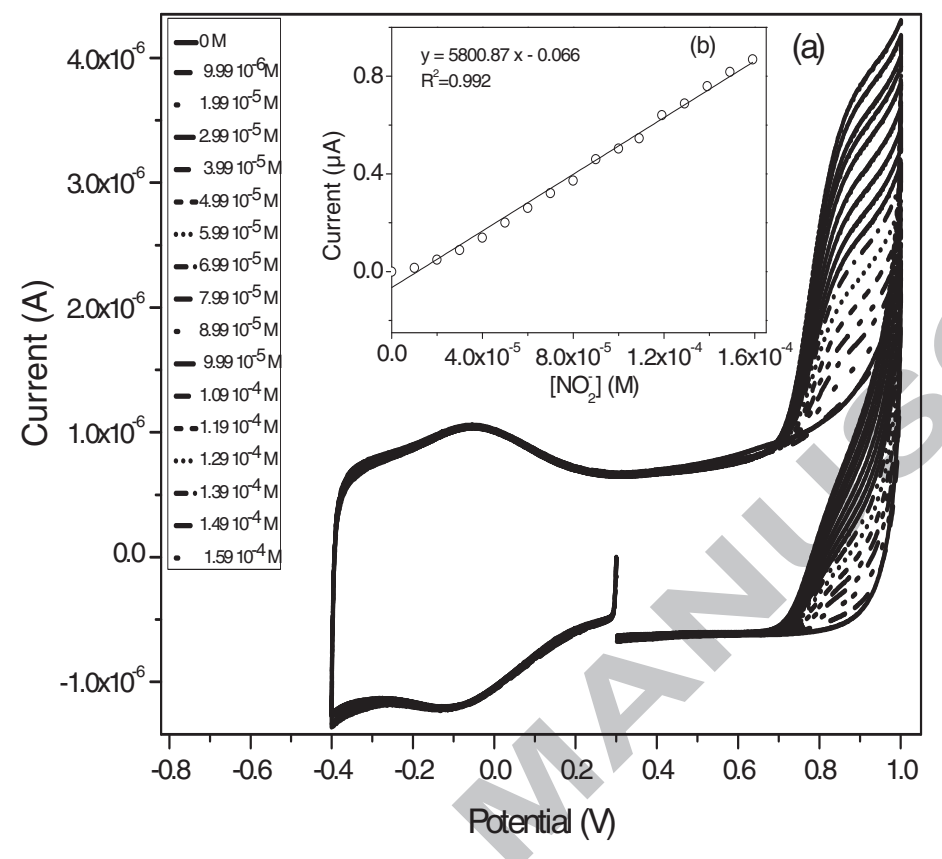

Figure 12. 


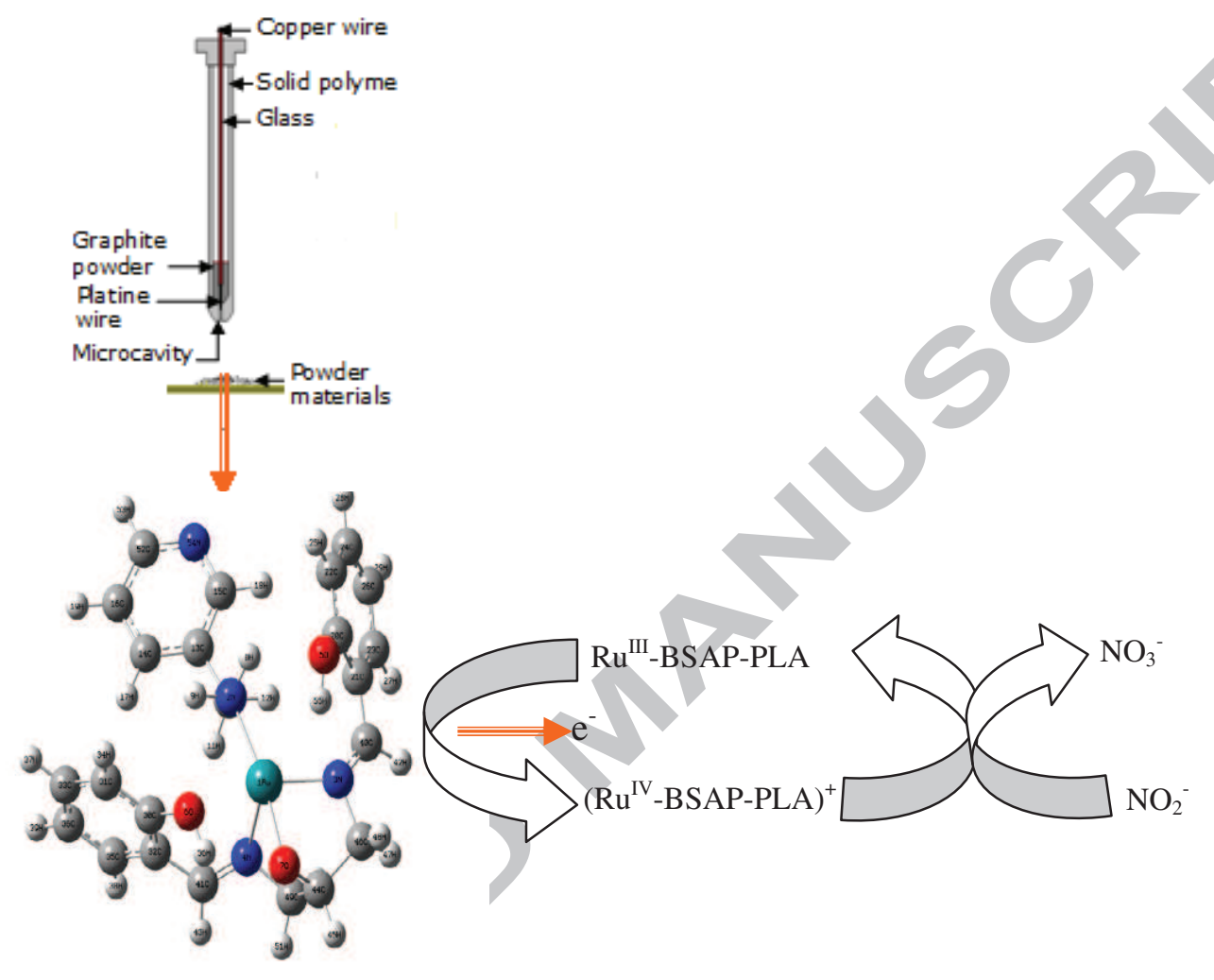




\section{Highlights}

- Ternary ruthenium(III) complex with 1,3-bis(salicylideneamino) propan-2-ol polydentate base Schiff (BSAP) and 3-Picolylamine (PLA) was synthesized, characterized and the structure was optimized using density functional theory.

- Graphite-Ru(III)-BSAP-PLA composite material was prepared and characterized by scanning electron microscopy coupled with energy dispersive spectroscopy (SEM-EDS).

- Cavity microelectrode (CME) was modified with graphite-Ruthenium(III)-BSAP-PLA material.

- Substantial electro catalytic effect of ruthenium(III)-BSAP-PLA complex on oxidation of nitrite was determined by using CME/G/Ru(III)-BSAP-PLA modified electrode. 